\title{
On Xuanzang and Manuscripts of the *Mahāprajūnāpāramitā-sütra at Dunhuang and in Early Japanese Buddhism
}

\author{
GEORGE A. KEYWORTH \\ University of Saskatchewan \\ george.keyworth@usask.ca
}

Abstract: Xuanzang 玄牀 (Genjō, c. 602-664) is credited with translating some of the largest and most significant scriptures and commentaries in the East Asian Buddhist canons. But his behemoth translation of the Mahāprajñāpāramitā-sūtra 大般若波羅蜜多經 $(Z$ no. $1, T$ no. 220) in 600 rolls seems to have been particularly important to Buddhist monastics and patrons who produced manuscript editions of the Buddhist canon at Dunhuang during the ninth century, and in Japan from the eighth to twelfth centuries. In this paper, I first survey what made the *Mahāprajñ $\bar{a} p \bar{a} r a m i t \bar{a}-$ sùtra an object of exceptional reverence, and why it appears to have been critical to

This research is generously supported by an Insight Grant from the Social Sciences and Humanities Research Council of Canada (SSHRC) and a SSHRC Partnership Grant (https://frogbear.org/). I would also like to thank Prof. Ochiai Toshinori, director of the Research Institute for Old Japanese Manuscripts at the International College for Postgraduate Buddhist Studies (ICPBS) in Tokyo for making it possible to access the digital archives at the ICPBS library. I would also like to express special thanks to abbot Otowa Ryūzen 音羽 隆全 Shōnin 上人, Ms. Inoue Sachiko 井上幸子, and Ms. Hirose Mitsuko 広瀬 美子 of Myōrenji 妙蓮寺, who have provided generous time and support for my many visits to this splendid Hokkeshū 法華宗 temple to see and learn about the Matsuo shrine scriptures and their conservation. 
communities from western China to Japan that this colossal work can be connected to Xuanzang. Next, I introduce several colophons to manuscripts from Dunhuang to show how quickly Xuanzang's Mahäprajūnāparamitā-sütra seems to have been taken to the temples near Dunhuang to become the key component in manuscript copies of all the scriptures (yiqie jing, issaikyo 一切經). Then I introduce less well known manuscripts from eighth century Japan, along with examples of rolls with colophons from the Nanatsudera 七寺 and Matsuo shrine 松尾社 canons, and archaeological evidence from elsewhere in Heian (794-1185) Japan to demonstrate how and why the Mahāprajñāpāramitā-sūtra was revered above all other scriptures.

Keywords: Mahāprajñāpāramitā-sūtra, Da bore jing, Dai hannya kyō, Xuanzang, Buddhist manuscripts China and Japan, Dunhuang manuscripts, old Japanese manuscript canons, Tang China, Matsuo shrine canon, Nanatsudera canon

DOI: https://dx.doi.org/10.15239/hijbs.03.01.08

Introduction: The Biggest (Or Longest) Buddhist Text in Chinese

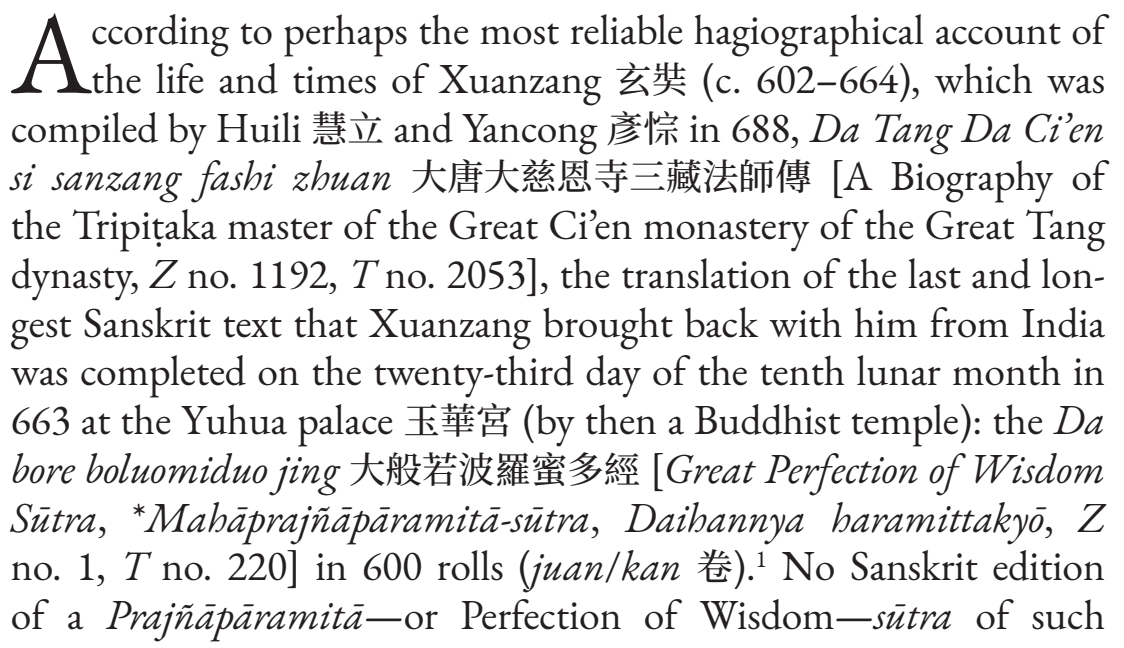


magnitude has been found, nor was such a large text translated into Tibetan. ${ }^{2}$ In his ample encyclopedic anthology compiled at Ximingsi 西明寺, Fayuan zbulin 法苑珠林 [Jade Forest in the Dharma Garden, $T$ no. 2122, 100 rolls], which contains, among other things, scriptural passages and Chinese Buddhist miracle tales, Daoshi 道世 (596?-683) reports that the Sanskrit manuscript Xuanzang and his team used to translate the first assembly (bui 會)—'meeting' or 'sermons'—of sixteen consisted of 132,600 ślokas (song 頌) rendered into 400 rolls in seventy-nine chapters ( pin 品; parivarta). ${ }^{3}$ Huili and Yancong report that the Sanskrit edition of this text had 200,000 slokas. ${ }^{4}$ One śloka of a Buddhist [hybrid] Sanskrit text has thirty-two syllables. ${ }^{5}$

Despite being one-sixth the size of the Da bore jing when translated from Sanskrit into 100 rolls in Chinese, the Yuqie [or Yujia] shidi lun 瑜伽師地論 [Yogacār[y] abbümi-śastra, $Z$ no. 690, $T$ no. 1579] that was completed on $648.5 .14^{6}$ - only three years after Xuanzang

1 Da Tang Da Ci'ensi sanzang fashi zhuan, T no. 2053, 50: 10.276c8-12; translated in Li, Tripitaka Master, 329.

2 In his Chos 'byung [History of Buddhism in India and Tibet, comp. 1322], Bu ston (1290-1364) says that an edition of the Prajñāparamitā in 1,000,000 slokas is preserved in the abode of the Gandharvas; an edition with 10,000,000 slokas in the land of the gods; and an abridged version [Śatasāhasrikā-prajūāpāramitā-sūtra, 100,000 slokas] exists in the land of the Nāgas. See Obermiller, History of Buddhism, 170; Conze, Prajñāpāramitā Literature, 25, note 34.

There is, of course, a distinction to be made between a translation and a version of a text; Chinese or Tibetan translations 'should not be regarded simply as "a translation" of the text but as "a version" representing a certain stage at which the text developed'. Karashima, Lokakṣema, xii; Apple, 'Dharmaparyāyo Hastagato', 27 , note 4 .

3 Fayuan zhulin, T no. 2122, 53: 100.1024b18-19.

4 Da Tang Da Ciensi sanzang fashi zhuan, T no. 2053, 50: 10.275c24-26; translated in Li, Tripițaka Master, 327. Fayuan zhulin, cited above, lists the total as 200,400 song.

5 Conze, Prajñāpāramitā Literature, VI, 27-28.

6 All dates in this format follow the East Asian lunar-solar calendar unless otherwise noted. 
had returned from India and the western regions (Xiyu 西域) to settle in Hongfusi 弘福寺 (alt. Xingfusi 興福寺) in Chang'an-is regarded by scholars of Buddhist philosophy and phenomenology as the most important of the production by Xuanzang and his team of seventy-seven works because it is 'the very scripture which triggered the Chinese master's extraordinary ability'. ${ }^{7}$ Yet, prior to the production of typeset [reproductions] of the Buddhist canon in Chinese in Japan during the late nineteenth and early twentieth centuries, and especially the now standard edition of the Taishō shinshü daizōkyō 大 正新脩大藏經 (1924-1932, 100 vols.), which follow bibliographical tips concerning categories to order Buddhist literature in Zhixu's 智旭 (alt. Lingfeng Ouyi 靈峰蕅益, 1635-1655) Yuezang zhijin 閱 藏知津 [(Buddhist) Canon Reading Guide, J. B271], ${ }^{8}$ Xuanzang's Da bore jing came first in all editions of the Buddhist canon after 730. In his Kaiyuan Shijiao lu 開元釋教錄 [Record of Śākyamuni's Teachings, Compiled during the Kaiyuan Era (713-741), $Z$ no. 1183, T no. 2154, comp. 730, Kaiyuan lu], Zhisheng 智昇 calls the Prajñāpāramitā the 'mother of all Buddhist sütras' and produced this 'epoch-making work in the history of Chinese Buddhist catalogues' because it organized and set the order of the sutras, commentaries (lun 論, śāstras), Vinaya (lü 律) literature, and selected works compiled in China (for example, Daoxuan's 道宣 [596-667] Guang Hongming $j i$ 廣弘明集 [Expanded Collection on the Propagation and Clarification (of Buddhism), $Z$ no. 1202, $T$ no. 2103, comp. 664] and $X u$ Gaoseng zhuan 續高僧傳 [Continued Biographies of Eminent Monks, $Z$ no. 1196, $T$ no. 2060, comp. 664]). ${ }^{9}$ Today, the

7 Deleanu, 'Yogācārabbūmi', 632. On the number of translations completed by Xuanzang and his team, see the abridged appendix to Lusthaus, Buddhist Phenomenology. Available at: http://www.acmuller.net/yogacara/thinkers/xuanzang-works.html, accessed on August 1, 2018.

8 Li, 'Chinese Buddhist Canon', 121-24. See also Wu et al., eds., Reinventing the Tripitaka, 82, 117, 208-09.

9 Li, 'Chinese Buddhist Canon', 112. See also Tokuno, 'Buddhist Bibliographical Catalogues', 52-53, 71, notes 97-98; Storch, History of Chinese Buddhist Bibliography, 116, 28-29; Wu, 'Cult of the Book'. Tokuno cites an entry in the 
Da bore jing comprises three [massive] volumes in the Taishō canon (vols. 5-7). Before the first edition of the Chinese Buddhist canon was printed in Sichuan in 983 (Shuban dazang jing 蜀版大藏經 or Kaibao zang 開寶藏), more than 5,000 rolls of the texts included in manuscript editions of the Buddhist canon (yiqie jing 一切經 or zhongjing 衆經 $)^{10}$ were kept in bundles (zhi; chitsu 帙) ${ }^{11}$ or perhaps

thirteenth century Fozu tongji 佛祖統紀, $T$ no. 2035, 49: 40.374c3-5, which says: 'The 5,048 rolls [that the catalogue contained] became the established number for the canon'. She also points out that the Xu Zhenyuan shijiao lu 續貞元釋教 錄, $T$ no. 2158, 55: 1048a23-26, says that the Kaiyuan lu circulated widely and continued to do so during the four courts of emperors Xuanzong 玄宗 (r. 712756), Suzong 肅宗 (r. 756-762), Daizong 代宗 (r. 762-779), and Dezong 德宗 (r. 779-805). There is an edition of the Kaiyuan lu from Nanatsudera copied from a manuscript dated to 735 (Tenpyō 天平 7) and brought back to Japan by Genbō 玄 昉 (d. 746) with 1,046 titles in 5,048 rolls, in contrast to the Taishō edition with 1,076 titles in the same number of rolls. See Abe, Chüsei Nibon, 199-200.

10 The term canon literally means 'all the jing', which cannot be restricted to sütra literature. In Chinese, a jing is a text that contains the teachings of ancient sages; hence the use of the term shengjiao 聖教 for Buddhism during the Tang (see below). But within the context of a canon, jing need not be restricted to Buddhists in China. Here is how Lewis Lancaster outlines the problem:

While the Chinese use the word jing in titles where the term sutra appears, the meaning of jing in the catalogues and in the name for the canon of the Buddhists retains its Chinese meaning. This restriction of usage for the word jing means the exclusion of any works which could not be traced to the distant past... The word jing was not limited to the Confucian and Buddhist traditions, and later the Daoists, Christians, and Manicheans would also use jing to provide legitimacy to the title of their scriptures. It was this focus on the ancient nature of any work, which bore the title jing, that helped to create the situation where contemporary Buddhist works of China were denied an avenue for distribution...Later, the name for the canon was changed to Dazang jing 大藏經 (literally great-collection jing)... We know that the canon contains more than those texts designated as sütra, so the term jing cannot be used solely as the equivalent for that one category (Lancaster, 'Movement of Buddhist Texts', 234-35). 
sometimes in elaborately decorated Chinese style chests (karabitsu 唐櫃) that we see in Japan which contain the twelfth century scrolls (kansubon 巻子本, rather than oribon 折本) of the Nanatsudera $七$ 寺 (Nagoya) or Matsuo shrine 松尾大社 (Kyoto) canons. ${ }^{12}$ The $\mathrm{Da}$ bore jing came first, whether systematized in bundles in premodern

Lancaster also points out that we can only date the use of the term dazang jing (daizōkyō) to mean a Buddhist canon to the Northern Song, when the first printed canon was sponsored by the state (Shuban dazang jing 蜀版大藏經 or Kaibao zang 開寶藏, comp. 983). Dazang jing or dazang jing, therefore, first meant all the jing from the great [monastic, private, or imperial] library. The Daoist canon (Zhengtong daozang 正統道藏, comp. 1445), likewise, ought to be translated as the 'Daoist library' of White Cloud Abbey 白雲觀 in Beijing. See Lancaster, 'Movement of Buddhist Texts', 234-36.

Lancaster restricted his research to dynastic histories, which seems justifiable given post-Tang, imperial patronage for canon projects in China. See also Funayama, Butten Wa Dou Kanyaku Sareta No Ka, 11-12. Funayama makes an important distinction between the East Asian Buddhist terms meaning 'all the collected scriptures' (Ch. yiqie jing, Jp. issaikyō), which he posits can be traced to the Taihe 太和 [3] reign period (ca. 479) of the Northern Wei dynasty (386-534) and was in use during the Northern and Southern Dynasties period (420-589). 'Collected scriptures' (Ch. Zhongjing, Jp. shukyō) was used more prominently in southern China from the mid-sixth century on, with canon [referring to the tripitaka] (dazang jing/daizōkyō), which was applied by the Tang government. See also Li, 'Chinese Buddhist Canon', 107-08.

11 On zhi and also 'bundle-wrappers' (zhizi 帙子), see Rong, Eighteen Lectures on Dunbuang, 489.

12 One hundred rolls of the Dai hannya kyo per box were kept for the Nanatsudera canon. The box with rolls 301-400 of this scripture from Nanatsudera has a colophon which reveals that the scripture was revolve-read-or tendoku 転読一for sixteen guardian deity kings (jūroku zenjinnō): 南無般若十六善神王 from Nara National Museum, ed., Special Exhibit, image 14-2, 42, 139. See also de Visser, Ancient Buddhism in Japan, 515-16.

Perhaps because the chests that contained the Matsuo shrine canon are less ornate than those from either Nanatsudera or Chūsonji 中尊寺 Nakao Takashi and Ikoma Tetsurō 生駒哲郎 refer to these chests as kyōbitsu 経櫃: Nakao 
Chinese libraries that may have looked somewhat like the contents of the Buddhist texts in Chinese (rather than Tibetan or Khotanese, for instance) found in the so-called library cave (no. 17) from the Caves of Unparalleled Heights (Mogao ku 莫高窟, a.k.a. Caves of a Thousand Buddhas, Qianfo dong 千佛洞) near the city of Dunhuang, in Gansu province, at the turn of the twentieth century or 100 rolls per chest (karabitsu) as in premodern Japan. ${ }^{13}$

Bearing in mind how problematical it can be to assess the popularity of certain specimens of Buddhist literature in one location (e.g., medieval China) to deduce information about another locale about which we may know comparably much less (e.g., Middle Period India, ca. first century CE to fifth/sixth century CE), ${ }^{14}$ in the first section of this paper, I introduce colophons (okugaki 奥書, shikigo 識語), or 'tailpieces', ${ }^{15}$ to rolls of the Dai hannya kyō from two manuscript editions of the Buddhist canon discovered-or rediscovered-in Japan in 1990 and 1993, at Nanatsudera (Tōenzan 稲園山 Nanatsudera), a small, relatively obscure and somewhat rundown temple affiliated with Chizan Shingonshū 智山真言宗, and Myōrenji 妙蓮寺, a Honmon Hokkeshū 本門法華宗 temple in Kyoto, respectively. ${ }^{16}$ For reference,

Takashi and Honmon hokkeshū daihonzan Myōrenji, eds., Kyōto Myōrenji $Z \bar{o}, 81-82$. An example of the chest for the Dai hannya kyō from the Chūsonji canon is included in Nara National Museum, Special Exhibit, xxx.

13 On the Dunhuang cache, see Schmid, 'Introduction', 964-65; Rong, Eighteen Lectures on Dunbuang, 5, 79-108.

14 Schopen, 'Mahāyāna and the Middle Period in Indian Buddhism', esp. $1-4$. Schopen's remark that especially "Larger” Perfection of Wisdom-that is in 18,000, 25,000, or 100,000 lines...' (2) are more evident in India and especially Gilgit may prove instructive to investigating how esteemed Xuanzang's Da bore jing was in manuscript editions from Dunhuang and Japan.

15 Regarding colophons from Dunhuang, see Giles, Descriptive Catalogue, x; Huang and $\mathrm{Wu}$, Dunbuang yuanwen ji.

16 On the canon discovered at Nanatsudera, see Nanatsudera issaikyō hozonkai, Nanatsudera; Ochia et al., Nanatsu-dera. It should be noted that a karabitsu from Nanatsudera is mentioned in de Visser, Ancient Buddhism in Japan, 515-16. 
I also mention several examples from the Amanosan Kongōji 天 野山金剛寺 (in southern Ōsaka) canon, which seems to be on the whole slightly less old and certainly has far fewer colophons than we find to rolls from either the Matsuo or Nanatsudera manuscript canons. ${ }^{17}$ Old Japanese manuscript Buddhist canons are not organized according to the Kaiyuan $l u$ as manuscript and printed canons

The canon discovered in the treasury house (hōzo 宝蔵) at Myōrenji, a Hokkeshū 法華宗 temple, belonged to and was kept at Matsuno’o (alt. Matsuo) shrine-temple complex (see below) until 1857, when it was bought by Shimada Yasaburō 嶋田弥三郎 and transferred to Myōrenji. Cf. Risshō University Academy and Nakao, 'Maboroshi No Issaikyo' Hakken, 2; Keyworth, 'Copying for the Kami', 162-63. Sagai, Shinbutsu Shügō, 71, note 6. Nakao and Honmon Hokkeshū Daihonzan Myōrenji, Matsuosha Issaikyō, 33. Shimada was apparently a prominent lay devotee at Honnōji 本能寺 (the temple where Oda Nobunaga 織田信長 [1534-1582] had famously been forced to commit suicide), where he came to know Nagamatsu Nissen 長松日扇 (1817-1890), who is regarded as the founder of a pre-Sōka Gakkai 創価学会-like lay Buddhist Lotus Sūtra (Hokkekyō 法華經, Saddharmapundarika-sūtra, $Z$ nos. 146, 148-149, $T$ nos. 262264) chanting group devoted to the teachings of Nichiren 日蓮 (1222-1282) called Honmon Butsuryū-shū 本門佛立宗, coincidentally founded in 1857. Cf. Takeda, 'Nagamatsu Nissen Ni Okeru Kyōka Katsudō No Kenkyū'.

Shrine records indicate that the building to house the scriptures at Matsuo shrine, see below, was destroyed in early 1864 (Bunkyū 文久 4/Genji 元治 1); the monastics were forced to return to lay life three months later.

${ }_{17}$ Although there are much later rolls in the Nanatsudera and Matsuo shrine collections, much of the Kongoji canon seems to have bee recopied during the seventeenth century; see Ochiai, ed., Kongōji Issaikyō, 152-313. One notable manuscript canon that deserves careful consideration is the canon vowed by Fujiwara no Kiyohara 藤原清衡 (1056-1128) for Chūsonji 中尊寺 in Ōshū Hiraizumi 奥州平泉. It was copied in gold and silver ink (probably on indigo paper) from 1108-1117. Also referred to as the Kiyohara vowed canon, 2,979 rolls of this canon, pledged to the newly established Kumano shrine 熊野神宮 in Hiraizumi, is called the Natori Shingūji canon 名取新宮寺一切経 and is one of the eight_or nine-extant manuscript canons in Japan. Ochiai et al., 'Découverte de manuscrits', 370-71. 
appear to have been on the continent. Instead they follow the slightly later Chinese Buddhist catalogue, Zhenyuan xinding Shijiao lu 貞 元新定釋教録 [Newly Revised Catalogue of Buddhist Scriptures, Compiled during the Zhenyuan Era (785-805), $Z$ no. 1184, $T$ no. 2157, hereafter Zhenyuan lu], compiled in 800, which means that they were copied to include 1206 titles in 5351 rolls. ${ }^{18}$ The Matsuo shrine canon is the earliest from twelfth century Japan. It was copied on behalf of father and son shrine priests (kannushi 神主) Hata no Chikatō 秦親任 (kannushi on 1076.2.20) and Hata no Yorichika 秦 頼義 (kannushi on 1128.8.12) for the Matsuo shrine-temple complex or multiplex (jingūji 神宮寺, alt. jinkuji 神供寺 or miyadera 宮寺), ${ }^{19}$ primarily over twenty-three years (1115 to 1138 ).

Today, 3,545 rolls (approx. 825 separate titles) of the Matsuo shrine canon survive with 1,236 rolls (approx. 345 titles) that have colophons with dates, collation information, the names of scribes, and information about which libraries had the texts copied for the Matsuo shrine canon. Colophons also indicate that monastic-scribes from Enryakuji 延暦寺 added, checked, or revised many scriptures

18 According to Cai Yunchen, Zangjing mulu, 267, printed canons did not include the Zhenyuan lu before the [second] Koryŏ edition, but it is mistaken to claim that printed canons were arranged according to the Kaiyuan lu: precisely what makes the Taishō a problematical but nonetheless invaluable resource is the fact that it incorporates so many ritual translations (mikkyōbu section 密教部, vols. 18-21) and ritual manuals translated after the Kaiyuan lu was completed, many of which are, of course esoteric or even Tantric. The same can be said for the expansive-though highly edited-inclusion of commentaries from China and Korea (kyōshobu 経疏部) in vols. 33-39, and 'sectarian' works (shoshūbu 諸宗 部) in vols. 45-48. T no. 2157 lists an alternative 1,258 titles in 5,390 rolls.

19 On jingüji and miyadera, see Sagai, Shinbutsu shügō, 105-10. For the term 'multiplex', see Grapard, 'Institution, Ritual, and Ideology'. And his synopsis in Shively and McCullough, eds., Cambridge History of Japan, chapter 8. See below and McMullin, Buddhism and the State, 8-32; Kornicki, The Book in Japan, 252-53. Cf. Keyworth, 'Apocryphal Chinese Books', 1-2. On the dates for Matsuo shrine priests, see Matsuno'o jinja higashimoto keifu in Matsuno'o taisha shiryōshū henshū iinkai, Matsuno'o Taisha Shiryōshū, 230-31. 
between 1139.1 and 1143.5.26; it appears that several of the scribes who copied scrolls for Hata no Chikatō and Hata no Yorichika were affiliated with both Enryakuji and rival Miidera 三井寺 (Onjōji 園城 寺). Furthermore, between 1159 and 1165, Ryōkei 良慶, the abbot of Myōhōji 妙法寺, one of two known temples in the southern valley (Minamidani 南谷) of the Matsuo jingüji precincts, vowed and added scriptures, which I presume largely came from the otherwise virtually unknown library of Bonshakuji 梵釈寺, near Ōtsu 大津 in Shiga prefecture 滋賀県. ${ }^{20}$ Ryōkei was almost certainly a Miidera monastic before taking up the position of abbot of Myōhōji.

The Nanatsudera canon consists of 4,954 rolls: 378 have colophons (158 separate titles) with dates or marginalia to indicate that the scriptures were copied in rough chronological order between 1175 and $1180 .{ }^{21}$ Recent archaeological excavations of the old site of Kumano hongū 熊野本宮 (Tanabe 田辺, Wakayama prefecture 和 歌山県) uncovered how, in the tenth lunar month of 1121, Hata no Chikatō sponsored burial in a sütra mound (kyozzuka 経塚) of the Dai hannya kyō divided into fifty rolls in each of twelve containers. ${ }^{22}$ Including the Dai hannya kyō, fourteen titles from the Nanatsudera canon have a six-line stamp (rokugyo inki 六行印記) that reveal how these scriptures were also copied and vowed to the kami $i$ 神 of Atsuta as well as protective gongen 守護権現 (avatāras) of fifteen others in central Japan. ${ }^{23}$ Both because they serve as representative precedents

20 Keyworth, 'Production of Manuscript Buddhist Scriptures and Canons'.

21 Ōtsuka, 'Issaikyō Shosha to Butten Mokuroku'.

22 Abe, Chūsei Nibon, 189; Kyoto National Museum, ed., Eastward Expansion of Buddhism, 104-05. Neither Hata no Chikatō nor Yorichika are listed in Hérail, Cour Et L'administration. Tokyo National Museum currently owns these relics from Sonaezaki kyōzuka 備崎経塚, see image E0068598 of J-37365 and the close up image of the inscription, E0068598 of J-37365.

23 The six-line stamp includes the names of the following kami: the great shining (or powerful) kami (daimyōjin) of Atsuta shrine, Yatsurugi no daimyōjin 八剱大明神, and the protective gongen of fifteen other shrines in central Japan. These include the Inner and Outer shrines at Ise 伊勢内外; Bonson who resides on Musan 梵尊土所牟山; Hakusan Myōri 白山妙理; the three shrines of 
from Japan and because the aforementioned colophons and internal evidence assures us that the twelfth century Matsuo, Nanatsudera, and Kongōji canons were primarily copied from manuscript copies of Tang dynasty (618-907) editions kept in now mostly long-forgotten libraries (e.g., Bonshakuji), in the next section, I introduce several examples of longer, 'dedicatory inscriptions' (okugaki ganmon 奥書願文 $)^{24}$ to eighth century manuscripts of the Dai hannya kyō from Japan. Next, I survey the evidence we have from Dunhuang of colophons from rolls of the Da bore jing copied primarily during the ninth century until the cave was probably sealed, ca. 1006. ${ }^{25}$ Finally, I address the contents of the Da bore jing and legends about Xuanzang and his translation team's production of it in the mid-seventh

Kumano 熊野三所; the Three Sages of Sannō 山王三聖; and three protective or tutelary shrines (chinjusha 鎮守社) of Tado 多度, Tsushima 津嶋, Nangū 南宮 and Chiyo 千代. The Inner shrine at Ise is, of course, dedicated to Tenshō daijin (Amaterasu); the Outer shrine is dedicated to Toyouke Bime 豊宇気毘売神. I have no idea what to make of Musan Bonson. Hakusan Myōri almost certainly refers to shrines to Shirayama Hime 白山比咩, a 'water-kami' (suijin 水神) in modern Gifu prefecture mentioned in Procedures of the Engi Era (Engishiki 延 喜式, 901-923, comp. 927 utilized after 967), which came under Tendai control during the twelfth century and was linked to the Mountain King (Sannō) network of shrines directed from Hiei 日吉社 (alt. Hiyoshi) in Sakamoto 坂本 (in Shiga), at the foot of Mount Hiei. Tada shrine, dedicated to Amatsuhikone 天津彦根, is located in Mie. Tsushima refers to an ancient shrine in Tsushima city, Aichi prefecture, where the kami of pestilence, Gozutennō 牛頭天王 (lit. ox-headed heavenly king), and Susanoo 須佐之男 reside. And the registry of official deities (jinmyōchō 神名帳) venerated at official shrines (shikinaisha 式内 社) in Engishiki lists a Nangū dedicated to Kanayamahiko no mikoto 金山彦之命 in the Fuwa district 不破郡 of modern Gifu prefecture. See Nanatsudera issaikyō hozonkai, Owari shiryō Nanatsudera, 5-128.

24 See Lowe, 'Contingent and Contested', 227; and Abe, Chüsei Nihon no shükyō, 177.

25 See Hansen, 'The Tribute Trade with Khotan'. Hansen follows Rong, 'Nature of the Dunhuang Library Cave'. See also Rong, Eighteen Lectures on Dunbuang, 5, 109-36. 
century to speculate about why it was revered above all other scriptures-with the possible exceptions of the Diamond (Jin'gang jing 金剛經, Vajracchedikā, $Z$ no. 15, T no. 235), Lotus (Fabua jing 法 華經, Saddharmapundarìka-sūtra, $Z$ nos. 146, 148-149, $T$ nos. 262-264), and Suvarnabhāsottama (Jin'guangming jing 金光明經, $Z$ nos. 158-159, T no. 663-665) sütras-in premodern Japan. ${ }^{26}$

\section{Manuscript Copies of the Dai Hannya Kyō in Twelfth Century Japan}

Perhaps the most striking difference between Japanese manuscript canons from the twelfth century and either the manuscripts from Dunhuang or parallel Buddhist texts with long colophons from eighth century Japan is that there is no duplication in the manuscript canons. In other words, whereas in the case of the Da bore jing-and certainly other Prajñāpāramitā sütra-manuscripts and manuscript fragments from Dunhuang, especially those copiously catalogued by Lionel Giles (1875-1958: 1935-1943; 1957) in the Stein collection, of which there are no fewer than 763 items and where we find duplicates of multiple rolls (e.g., roll 267: S. nos. 1579, 4830, and 5351), ${ }^{27}$ in the Shōgozō 聖語蔵 repository from Tōdaiji 東大寺, located next to the Shōsōin 正倉院 treasure house in Nara, Japan, ${ }^{28}$ or in the Matsuo shrine, Nanatsudera, and Kongōji manuscript canons we find no duplicate texts.

Among the many things we can learn from the manuscripts or manuscript fragments of Buddhist texts in Chinese-or Tibetan,

26 In neither the Matsuo shrine canon-where Kumārajīva's translation ( $Z$ no. $146, T$ no. 262 ) is entirely missing-nor the Nanatsudera canon does the Lotus seem to have received any special attention. Yet others have written extensively on the recognition of the Lotus Sütra in medieval Japan; see McMullin, 'The Lotus Sutra and Politics'; Tanabe and Tanabe, eds., Lotus Sutra in Japanese Culture; Bielefeldt, 'The Lotus Sutra in Japanese Culture'.

27 Giles, Descriptive Catalogue, 7. For ease of finding examples digitized on http://idp.bl.uk/ I use S. nos. rather than the serial nos. given in this catalogue.

28 Jōdai bunken o yomu kai, ed., Jōdai Shakyō Shikigo Chūshaku. 
Khotanese, and so forth-from Dunhuang, Chinese Central Asia (Xinjiang), Northwestern India (Pakistan, Afghanistan), and Japan is that many, many Mahāyāna texts that were catalogued during the eighth century in China unambiguously exalt the five practices of the preacher of the buddhadharma (dharmabhänaka)-preserving, reading, reciting, explaining, and copying the sütra or 'nonmeditational' or 'meritorious' acts (kuśalena karmañā) — to obtain what Gregory Schopen and others have characterized as a 'cult of the book' [in the Mahāyāna]. ${ }^{29}$ Elsewhere I have examined colophons to rolls from the five great Mahāyāna sūtras or compendia (gobu daijōkyō 五部大乗經, 165 rolls in eighth to ninth century editions of these texts) ${ }^{30}$ from the Matsuo and Nanatsudera manuscript canons, and especially to rolls from Buddhabhadra's 佛陀跋陀羅 (ca. 418-422) translation in sixty rolls and Śikșánanda's 實叉難陀 (ca. 699; $Z$ no. 96, T no. 279) in 80 of the Buddhâvatamsaka (Huayan jing 華嚴經, $Z$ nos. 95-96, $T$ nos. 278-279) from Matsuo that have a long clan

29 Schopen, 'The Generalization of an Old Yogic Attainment', 114. On the 'cult of the book in the Mahāyāna', see Schopen, 'Phrase Sa Pṛthivīpradeśaś Caityabhūto Bhavet'. Updated for the twenty-first century by Schopen, 'On the Absence of Urtexts and Otiose Ācāryas'; Schopen, 'Redeeming Bugs, Birds'; Drewes, 'Revisiting the Phrase'; Gummer, 'Listening to the Dharmabhāṇaka'; Apple, 'Dharmaparyāyo Hastagato'. On the five practices, see Lopez, The Lotus Sütra, 69.

30 Mujaku Dōchū's 無著道忠 (1653-1745) encyclopedia, chapter 21, Mujaku, Zenrin Shōkisen, 590-91, cites Tiantai Zhiyi's 天台智顗 (538-597) Fabua xuanyi 法華玄義 5, T no. 1716, 33: 5.732c28-733a2, read as follows: 既得論悟與不悟, 何妨論於淺深? 究竟大乘, 無過《華嚴》、《大集》、《大品》、 《法華》、《涅槃》, 雖明法界平等、無說無示, 而菩薩行位終自炳然. The order that Zhiyi gives corresponds to his well-known panjiao 判教 system in which the Buddhāvatamsaka is considered the ultimate, mostly incomprehensible scripture, Prajñāpāramitā literature represents median difficulty in terms of apprehension, and the Lotus Sütra plays the role of the most clear and lucid presentation of the buddhadharma. Cf. Liu, 'P'an-Chiao System'; Liu, 'P'an-Chiao'; Liu, 'Advent of the Practice of P'an-Chiao'; Hu, 'Elevation'. Cf. Sagai, Shinbutsu shūgō, 71, note 6. Nakao Takashi and Honmon Hokkeshū Daihonzan Myōrenji, Matsuosha Issaikyō, 33. 
vow (ichizoku kechien 一族結縁), to illustrate how Chikatō had the merit accrued from the act of having them copied transferred to his extended family. ${ }^{31}$

No rolls to the Dai bannya kyo from Matsuo have this long clan vow. The Dai hannya kyō preserved at Matsuo jingūji within the Godokyōjo 御読経所 (the building where scriptures were read or recited) - see the undated roll $522^{32}$ - until the chests that contained the rolls of the canon were acquired by Shimada Yasaburō 嶋田弥三 郎 in 1857 seems to have been mostly copied not for Matsuo at all, but instead by scribes from cloisters of Enryakuji 延暦寺 on Mount Hiei 比頻山 to be read-or recited-on specific ritual occasions. These include a 'lecture series' (kaikō) $)^{33}$ within the Saitōin (Western Pagoda) section of Enryakuji (於天梯西塔院所奉開講也) held on 1063.9.11 when rolls 124, 142, 143, 146, 191, and 197 of the Dai hannya kyo were vowed to be recited in order to avert rebirth in the realm of hungry ghosts (gaki, preta) as follows: tame ni sukü gaki no michi nari 為救餓鬼道也. ${ }^{34}$ The following year, on 1064.8.9, rolls 203, 208, and 252 were repeatedly recited (the words were infused or impregnated) during a ritual service (kuyo 供養; $p \bar{u} j \bar{a})$ held at the Shōkyōin 勝境院 in the Yokawa section of Enryakuji (於天台山橫川勝 境殊所熏修也) in order to prevent rebirth in the realm of animals: tame ni rein chikushō no michi no gunrui nari 為令引攝畜生道之群類也. ${ }^{35} \mathrm{On}$

31 The clan vow is translated and an overview of these 18 scriptures is presented in Keyworth, 'Apocryphal Chinese Books in the Buddhist Canon at Matsuo Shintō Shrine', 16. On kechien, see Teiser, Ten Kings, 160-61; Kieschnick, Impact of Buddhism, 158; Nakano, 'Kechien', 67-83.

32 On the reverse we find: 松尾社御讀経所. Large characters read: 大般若也. Cf. 27/377 in Nakao \& Honmon Hokkeshū Daihonzan Myōrenji, Matsuosha Issaikyō, 201.

33 On officially sponsored lecture series in Heian Japan, see Sango, 'Buddhist Debate'; Halo of Golden Light.

34 See notes 93, 107, 108, 110, 148, and 153 in Nakao \& Honmon Hokkeshū Daihonzan Myōrenji, 'Matsuosha Issaikyö, 199-200.

35 See notes 159, 164, and 195 in Nakao \& Honmon Hokkeshū Daihonzan Myōrenji, 'Matsuosha Issaikyö', 199-200. 
the seventeenth day of the first lunar month of 1065, rolls 301-304, $306,309,311,317$, and 318 were vowed at another ritual service held at Kamigamo and Shimogamo 下鴨 shrine (於賀茂下御社敬以供養) to prevent rebirth in the realm of asuras: tame ni nasu asura no michi nari 為濟阿修羅道也. ${ }^{36}$

In addition to rolls of the Dai hannya kyo preserved within the Matsuo shrine canon that can be connected to ritual occasions at cloisters on Mount Hiei or almost certainly sponsored by Tendai 天台宗 monastics at Kamo Shimogamo shrine during the late eleventh century, roll 312 bears a twelfth century dedication about how Yorichika had this roll vowed for the actual manuscript canon (Ganshu Matsuno'o kannushi Hata Sukune no Yorichika 願主松尾 神主秦宿禰頼義). ${ }^{37}$ The colophon provides information about the geographical extent of the network of shrine priests, Buddhist monastics, patrons, and scribes involved in compiling a complete copy of all 600 rolls of the Dai hannya kyo for Matsuo. This colophon tell us first, in red ink, that it was checked (and possibly corrected: $i k k \bar{o}$ ryō 一校了), and then in black in that it was copied on 1131.6 .16 by a scribe named Shūsei 宗清 at Kōfukuji 廣福寺, located within the precincts of a domain owned by Ise shrine 伊勢神宮 (specifically the Naikū 内宮) then called Tōtōmi no kuni (today in Hamamatsu 浜 松, Shizuoka province 静岡県) Kaba no Mikuriya 遠江國蒲 [Nagakami 長神] 御厨. The colophons also reveals that Yorichika had this roll vowed for Matsuo, along with his mother who was from the famed Minamoto clan 源氏. ${ }^{38} \mathrm{I}$ am uncertain what to make of the

36 See notes 239-44, 246, and 249-50 in Nakao \& Honmon Hokkeshū Daihonzan Myōrenji, 'Matsuosha Issaikyō', 200-01.

37 Roll 312 (19/247) in Nakao \& Honmon Hokkeshū Daihonzan Myōrenji, 'Matsuosha Issaikyö', 200.

38 The narrative of how the Minamoto clan defeated the rival Ise Taira clan 伊 勢平氏, and especially Taira no Kiyomori 平清盛 (1118-1181) and his son, Taira no Shigehara 平重衡 (1158-1185), who had been court retainers but usurped power in 1179 , thereby forcing prominent nobility and retired emperor GoShirakawa 後白河 (1127-1192, r. 1155-1158) to call in the troops from Kantō 関東 from their base in Kamakura is among the best known tales in Japanese his- 
line, fu koeru ikku bōdoku ryō 不越一句奉讀了, which means that not more than a line-or a few-was recited at Kōfukuji. Roll 347 has a colophon with the date of 1217.4.17, which tells us that because the scribe, Ryōkaku, did not [correctly] make a vow [against] his evil [karmic acts] to produce good merit [by copying this roll] to erase the [karmic seeds] and transgressions, it remained unfinished when he died at 74 sai (未起書寫了 此卷亡, 仍不願惡筆, 為滅罪生 善如件 僧良覺 七十四歲). ${ }^{39}$ Finally, colophons to the undated rolls 519, 523, 529-530, 549-550, and 591-593 simply inform us that these rolls were checked (or corrected) using the [manuscript] canon from Shitennōji (一校了 以四天王寺本經). ${ }^{40}$

Other than roll 312 of the Dai hannya kyo from the Matsuo

tory. See Adolphson, Gates of Power, 125-84. That lands seized from Shigehara were donated by Yoshitsune to Enrō to construct Saifukuji means that Matsuo jingüji-and the Hata clan shrine priests-were receiving support from the Minamoto at a time when Japan was engaged in its first truly catastrophic war (Genpei War 源平合戦, 1180-1185). If we can trust Kokan Shiren's account in Genkō shakusho, then not only did Enrō perhaps save the eyesight of chief shrine priest-for only the fifth lunar month in 1184-Hata no Yoriyasu by instructing him to rebuild the primary sacred hall (shinden 神殿) and placing 'relics' (shari 舎利; sarira) inside it, but he must have also made a catastrophic mistake because a tree landed on the roof damaging it during a thunderstorm in the seventh lunar month of 1196. Cf. Kokan and Fujita, Kundoku Genkō Shakusho, 337. Only after the relics were properly installed within a three-story pagoda ( $t \bar{o}$ 塔; stūpa) and the Lotus Sütra was recited were the kami of Matsuo appeased. An excellent reason to trust Kokan Shiren is a document preserved at Matsuo shrine, perhaps with the Buddhist canon before it was bought by Shimada Yasaburō, Minamoto no Yoritomo gejijo 下知状 (dated 1196.6.17), which substantiates the claims about land donated to Matsuo jingūji by the most powerful man in Japan during the twelfth century Matsuno'o taisha shiryōshū henshū iinkai, 1, 33-34. See also Blair, 'Rites and Rule'.

39 See note 274 in Nakao \& Honmon Hokkeshū Daihonzan Myōrenji, 'Matsuosha Issaikyö', 200.

40 See notes 374, 378, 381-382, 389-390, 429, and 431 in Nakao \& Honmon Hokkeshū Daihonzan Myōrenji, 'Matsuosha Issaikyō', 201. 
shrine canon, of which approximately seventy percent of the 600 rolls are extant, we have little information with which to conclude that this massive suttra was copied either at or directly for Matsuo jingüji. Instead, it appears that rolls were copied from as far away as present-day Shizuoka prefecture or perhaps donated to Hata no Chikato by monastics from cloisters of Enryakuji during the first few decades of the twelfth century when he commenced the process to produce a separate canon for Matsuo. The rolls of the Dai bannya kyo from the Nanatsudera canon speak to a different conclusion. Excluding instances in which the first and second rolls of every ten (i.e., rolls $10-11,20-21,150-151,580-581$, etc.) are no longer extant, we find the six-line stamp (rokugyo inki) that shows how these scriptures were copied and vowed to the kami of Atsuta and protective gongen of fifteen other kami (or shrines) in central Japan one every tenth and eleventh roll. Most are dated and list the names of the scribe and proofreader. ${ }^{41}$ Eshun 榮俊 seems to have been the chief proofreader, but the names of Ryūkei 隆慶, Ryōgō 良豪, Eige 永藝, Ezō 榮增, Ingō 院豪, Tōin 道胤, and Keiyūshi 慶有 之 also surface in the same role. Scribes names include: Keishun 慶 俊, Egi 榮義, Renyū 蓮遊, Enin 榮仁, Chōshō 長昭, and many more. At this stage of my research into the history of the compilation of the manuscript canon copied for Atsuta and other jingüji, but rediscovered at Nanatsudera first in the mid-1960s and again in 1990, it looks like this canon was also primarily copied from Tendai libraries-or those with copies from Tendai libraries. I base this preliminary conclusion on the colophon to roll 531 of the Dai bannya $k y o$ from Nanatsudera, which can also be found on roll 29 of the Zhenyuan $l u$ in the same collection. ${ }^{42}$ This colophon has marks in red ink and notation about how the scribe who copied these rolls simultaneously checked an edition from the scriptures in gold characters at Hosshōji 法勝寺, Fushimi shrine 伏見稲荷社, and Bonshakuji; the Hosshōji edition was to the scribe's right, the Fushimi

41 Nanatsudera issaikyō hozonkai, Nanatsudera issaikyō mokuroku, 202-20; Ochiai et al., Nanatsu-dera; and Ōtsuka, 'Issaikyō Shosha'.

42 Nanatsudera issaikyō hozonkai, Nanatsudera issaikyō mokuroku, 190-91. 
shrine edition to the left, and Bonshakuji above. ${ }^{43}$ Roll 531 is dated 1175.7.28.

There are three instructive undated rolls from the Kongōji canon with short colophons that can be used to interpret the six-line stamps on many, many rolls from Nanatsudera and the colophons from the eleventh century from Enryakuji cloisters-and Kamo shrine-in the Matsuo shrine canon, which vow to avoid injurious rebirths in the next life. Rolls 62(a) and 374(a) of the Dai bannya kyo from Kongōji have the following vows: gan i shosha zen 願以書寫善, eshi rokudosei 迴施六道生, shinso (alt. shinsho) kechien tō 親踈結緣等, kyōshō mujō $d \bar{o}$ (or michi) 共證无上道, nikkō 二交. I translate this vow as follows: I vow the good [merit accrued from the act of] copying [this text] [to be] transferred [to the] donor [on behalf of his/her next] [re-] birth, to form a karmic connection for all [his/her] imperfect relatives, to [serve as] proof of the unexcelled [Buddhist] path; proofread twice.

There are several very good reasons to presume that, as Marinus Willem de Visser (1875-1930) did in his posthumously published and encyclopedic Ancient Buddhism in Japan: Sutras and Commentaries in Use in the Seventh and Eighth Centuries A.D. and their History in Later Time (1935), the Dai hannya kyō was copied, read, and ritually recited (tendoku 転読) in mid- to late-Heian Japan because the Suxidi jieluo jing 蘇悉地羯羅経 (Susiddhikaramahätantrasādanopāyikapatala-sütra, $Z$ no. 509, $T$ no. 893), translated by Śubhakarasiṃha 善無畏 (in 726), told monastics and literati secular

43 Ochiai et al., 'Découverte de manuscrits', 370. Ōtsuka, 'Issaikyō Shosha'; Akao, 'Koshakyō Shi', 798-800; Keyworth, 'Apocryphal Chinese Books', 3. Please note that before I was generously given access to view a digital PDF of this roll (貞 1184-029) at the library of the International College for Postgraduate Buddhist Studies 国際仏教学大学院大学 in Tokyo on May 17, 2017, in that article I translated from a French translation of an article Prof. Ochiai presumably wrote in Japanese. Part 2 on page 370 states: 'version du Hōshōji (sic) cochée avec un trait rouge à droit; version de Fushimi (inconnue), cochée avec un trait rouge à gauche; version du Bonshakuji, cochée avec un rond noir au centre'. In the PDF scan, one can see the red line sloping to the right of $u$-ten and a faint red circle above sei-ten. 
officials to. ${ }^{44}$ If one fails to receive the desired results after following the customarily detailed ritual instructions in this 'esoteric' (mikkyo 密教) Buddhist manual, ${ }^{45}$ in chapter 37 on 'Rites for retrieving an article for effectuation that has been stolen' (Beitou chengwu quezheng fa pin 被偷成物却徵法品), one is told to 'beg for food, apply yourself diligently to recitation, generate great respect [for the Buddhas], and visit the eight holy sites [associated with the Buddha Śākyamuni], making obeisance as you proceed', or just ritually 'read the Mahāprajñā[paramita]-sütra either seven times or one hundred times, or take special things and donate them to the Sangha ${ }^{46}$ But coupled with rolls 124, 142-143, 146, 191, 197, 203, 208, 252, 301-304, 306, 309, 311, 317-318 and our undated colophon to rolls 62(a), 374(a), and 540(a) of the Dai hannya kyō from Matsuo and

44 De Visser, Ancient Buddhism in Japan, 495.

45 Mikkyō or 'esoteric' Buddhism is defined in ancient and medieval Japan in terms of guided cultivation of the Diamond (Kongokai 金剛界) and Womb (Taizōkai 胎藏界) mandalas from the Vajraśekhara-sütra (Jin'gangding jing, Kongōchōkyō 金剛頂經, $Z$ no. 517, T no. 865) and Mahāvairocana sūtra (Dari jing, Dainichikyō 大日經, $Z$ no. 503, $T$ no. 848). On these two mandalas (ryōbu mandara 両部曼茶羅) in Japanese esoteric Buddhism, see Ryuichi Abé, Weaving of Mantra. For philological context, see Giebel, Two Esoteric Sutras; 'Taishō Volumes 18-21'. The full title of the Vajrasekhara-sütra is Jin'gangding yiqie rulai zhenshi dasheng xianzheng dajingwang jing 金剛頂一切如來眞實攝大乘現證大經 王經 ('Sarvatathāgatattvasamgra-hamahāyānābhi-samayamahākalparāha-sūtra), attributed to Amoghavajra. See also the translation by Vajrabodhi, Jin'gangding yujia zhonglüe chu niansong jing 金剛頂瑜伽中略出念誦經 ( $Z$ no. 516, $T$ no. 866), and Giebel, trans., 'The Chin-Kang-Ting Ching Yü-Ch'ieh Shih-Pa-Hui Chih-Kuei'; Two Esoteric Sutras; 'Taishō Volumes 18-21'. The full title of the Dari jing is Dapiluzhena chengfo shenbian jiachi jing 大毘盧遮那成佛神變加持 經 (Mahāvairocanābhisambodhivikurvitaadhișthāna-sütra)', in Giebel, trans., Vairocanābhisambodhi Sūtra.

46 Suxidi jieluo jing, T no. 893a, 18: 3.19-24c, in Giebel, trans., Two Esoteric Sutras, 306. The Chinese reads: 若不成者, 重加精進. 又更念誦, 作成就法. 如是 經滿七遍. 猶不成者, 當作此法, 決定成就. 所謂乞食精勤念誦, 發大恭敬. 巡八聖 迹, 禮行道. 或復轉讀《大般若經》, 經七遍或一百, 或持勝物, 奉施僧伽. 
Kongōji, respectively, suggests that reading how to use this massive scripture may have less to do with so-called 'esoteric' Buddhist practices and much more to do with simply following the instructions in this and other Perfection of Wisdom sütras translated into Chinese. In fact, Xuanzang's Da bore jing consists of nearly every version of Perfection of Wisdom literature available in either Sanskrit or Chinese translation by the mid-seventh century.

\section{Patterns of Copying and Ritually Reciting the Dai Hannya Kyō from Eighth to Eleventh Century Japan}

Legend has it that Xuanzang returned from India with three editions in Sanskrit of the ${ }^{*}$ Mahāprajñāparamitā-sūtra. ${ }^{47}$ Following Huili and Yancong's hagiographical account in Da Tang Da Ci'en si sanzang fashi zhuan, considerable attention is awarded to the story of how Xuanzang approached translating the Da bore jing in the two most widely read books about Xuanzang by Arthur Waley (18891966) and Sally H. Wriggins. I think that Waley rightly chose to highlight that, after moving to Yuhua palace, Xuanzang and his team of twelve 'experts in Buddhist literature', among whom were the aforementioned Huili, Daoxuan, who wrote another earlier biography of Xuanzang and compiled several large compendia, the 'philologist' Xuanying 玄應 (d. 661: composed Da Tang zhongjing yinyi 大唐衆 經音義 [Sounds and Meanings of All the Scriptures during the Great Tang]), and nine 'phrase-connectors' (zbuiwen 経文), tackled the comparatively short Vijñaptimātratāsiddhi-sástra (Chengweishi lun / Joyuishikiron 成唯識論, $Z$ no. $734, T$ no. 1585) first in $659 .{ }^{48}$ Subsequently in 661, while working on the ${ }^{*}$ Mahäprajñāpāramitā, they also completed the Vimśatikāvrtti (Weishi ershi lun / Yushikinijüron 唯識二十論, $Z$ no. 731, $T$ no. 1590). Unlike when he and his team debated whether or not to produce an abridged translation of these

\footnotetext{
47 Waley, Real Tripitaka, 126.

48 Waley, Real Tripitaka, 85. See also Li, 'Chinese Buddhist Canon', 180; Wriggins, Silk Road Journey, 195.
} 
short, seminal Yogācāra treatises, Xuanzang apparently set his mind to wrestle with each and every line of the ${ }^{*}$ Mahāprajñāpāramitā after he had nightmares about being 'precariously poised on the edge of a frightful abyss or was being attacked by wild beasts' ${ }^{49}$ It would appear that the decision to persevere paid off because, according to Huili and Yancong, the abbot of Yuhua monastery and a member of the translation team had the same dream in which they saw Yuhuasi adorned with pennants, curtains, carts, and banners with musicians playing marvelous music in the courtyards while each and every monastic came to make offerings to the Da bore jing, just as described in the text. ${ }^{50}$ Moreover, as soon as the Da bore jing was completed, Xuanzang folded his palms together and declared:

This sutra has a special relationship with the land of the Han people. It is on account of this sutra that I have come to this Yuhua Monastery. If I had stayed as before in the capital, where there were many miscellaneous affairs to distract my mind, how could I have finished the work in time? It is with the spiritual assistance of the Buddhas and under the protection of the dragons and deities that I have completed the task. As this is a text that will guard the nation and a great treasure of men and heavenly beings, you all should rejoice and be glad at its completion. ${ }^{51}$

Then the rector of Yuhuasi, Jizhao 寂照, prepared a vegetarian feast and a ritual offering service for the monks. On the day when the sūtra was taken from Sucheng Hall 肅誠殿 to Jiazhou Hall 嘉壽殿 for the feast and to be lectured on and recited, a bright light emitted from the text and flowers fell from the sky. Music was heard in the air accompanied by an unusual fragrance. Having witnessed these miracles, Xuanzang was extremely pleased and said to his disciples:

\footnotetext{
49 Waley, Real Tripitaka, 125.

50 Da Tang Da Ci'ensi sanzang fashi zbuan, T no. 2053, 50: 10.276a16-27, translated in Li, Tripitaka Master, 328-29.

51 Da Tang Da Ci'ensi sanzang fashi zbuan, T no. 2053, 50: 10.276b10-14, translated in Li, Tripitaka Master, 329-30.
} 
It is recorded in the sutra itself that in this country there will be people taking delight in Mahayana teachings. All kings, ministers, and followers of the four groups who copy, receive, and keep it, as well as recite and circulate it will be reborn in the heavens and obtain ultimate emancipation. Since there is such a passage, we must not keep silent about it. ${ }^{52}$

Primarily relying on the Six National Histories (Rikkokushi 六国 史, comp. 720-901), Kokan Shiren’s 虎関師錬 (1278-1346) Genkō shakusho 元亨釈書 (Buddhist History of the Genkō Era [13211324]), and secondary studies in Japan available before the Second World War, de Visser's pioneering study delineates how certain key Mahāyāna sūtras were utilized as early as 735 in ancient Japan for 'state protection' (chingo kokka 鎮護国家) rituals that were performed with special attention to ritualized readings (either chanting [dokuju 読誦] or revolve-reading [tendoku]) of three scriptures-(1) Xuanzang's translation of the Dai hannya kyō, (2) the Suvarnabbāsottama-sütra, and (3) the Renwang jing 仁王經 ( $Z$ no. 21, T no. 245 and $Z$ no. 22, $T$ no. 246: Shin'yaku ninnōkyo 新訳仁王經 $)^{53}$ -

52 Da Tang Da Ci'ensi sanzang fashi zhuan, T no. 2053. 50: 10.276b14-21, also translated in Li, Tripitaka Master, 330. The Chinese reads: 時玉華寺都維 那寂照, 慶賀功畢, 設齋供養. 是日, 請經從肅誠殿往嘉壽殿齋所講讀. 當迎經時, 《般若》放光, 諸天雨花, 并聞空中音樂, 非常香氣. 既覩靈瑞倍增嘉慰, 謂門人 日：“經自記此方當有樂大乘者國王、大臣、四部徒眾，書寫受持，讀誦流布，皆得 生天, 究竟解脫. 既有此文, 不可緘默.' 至十一月二十日, 令弟子窺基奉表奏聞, 請御製經序. 至十二月七日, 通事舍人馮茂宣勅垂許.

53 See 'Chingo kokka' 鎭護國家 and 'Chinju' 鎮守 in Lévi et al., Hōbōgirin, 1 (1929), 2 (1930), 3 (1937), 4 (1967), 5 (1979), 6 (1983), 7 (1994), 8 (2003), 9 (nd) vols., 322-27. The former entry explicitly points out that protection from or for kijin 鬼神 (a blanket term in Chinese for 'gods') almost always involved dhärañi, and particularly from the Ninnōkyō (see T no. 245, 8: 829c29-830a4 [chapter 2]; and T no. 24, 8: 834c25 [chapter 1]) or Konkōmyōkyō (Suvarnabhāsottama-sütra, see $T$ no. 663, 16: 341b13-c3 [chapter 2]; $T$ no. 664, 16: 382c321 [chapter 5], and $T$ no. 665, 16: 427c6-27 [chapter 6]). Not only does de Visser pay ample attention to matters of 'state protection' Buddhism (Chingo 
usually on behalf of the kami (shinzen dokyō 神前読経) to avert natural disasters and calamities and protect the state and powerful clans (為消除災害 安寧國家也). ${ }^{54} \mathrm{~A}$ document preserved in the Shōsōin dated 735, Chishiki ubasoku kōshinbun 知識優婆塞貢進文 (Record of Tribute by Kalyāṇamitras, Upāsakas, and Aristocrats), is perhaps

kokka), but he provides the most thorough summary in English of the history of offerings of issaikyō [in Japan] from 651 to 1323; de Visser, Ancient Buddhism in Japan, 226, 605-15. Furthermore, de Visser provides the first clue in any European language that I know of about shrines where an issaikyo was offered or vowed to the kami, 'From the beginning of the twelfth century the Issaikyo festivals were often held in Shintō sanctuaries (Hiyoshi, Kumano, Iwashimizu, Gion, Kamo)' (de Visser, Ancient Buddhism in Japan, 611-12). His study also contains obliging references to how Enchin, see below, in particular, played an especially prominent role in promoting Tendai rituals - and orientated doctrines at debates and lectures-within the ritual system of Heian Japan.

On ritual readings of the Dai hannya kyō, see Sagai, Shinbutsu shūgō, 139-42; Abe, Chüsei Nibon, 430-50 and 196-98. The precedent for ritual readings of this large compendium in Japan comes from a hagiographical biography of Xuanzang, Da Cien sanzang fashi zhuan 10, T no. 2053, 50: 10.276b5-22, which says that a special lecture was delivered on this scripture and it was read at a ceremony on 663.10. Cf. Komine et al., Hannyakyō taizen, 372-82. On Issaikyō-e, see Blair, 'Rites and Rule', 6; Real and Imagined, chapter 1.2 and 1.3. See also Moerman, Localizing Paradise, chapter 4 (cited in Blair); and Moerman, 'Archaeology of Anxiety'.

On the Renwang jing (Ninnökyō) in China, see Orzech, Politics and Transcendent Wisdom. See below for the Konkömyökyō.

'State' in 'state protection' Buddhism remains a problematical term, not only because of the European context for 'state' (Peace of Westphalia, 1648) in English, but also because kuni (guo) may not have meant a 'state' in premodern Japan or China. In Nara or Heian Japan, for example, kuni meant something much closer to province as in where Matsuo shrine was located: by the turn of the eighth century, the Kadono district (Kadono no koori 葛野郡) of Yamashiro [no kuni] province 山城国, which roughly corresponds to Nishigyōku 西京区 and southern Ukyōku 右京区 (wards) today.

54 Komine et al., Hannyakyō taizen, 375; McCallum, Four Great Temples, 455-56, 495-500. 
the earliest document that outlines how specific sütras were recited at shrines (not yet jingūji) including Kamigamo 上賀茂社 (Upper Kamo shrine). ${ }^{55}$ Throughout albeit late editions of the Six National Histories carefully mined by de Visser, we learn how meticulously it appears that members of the imperial family in Japan, as well as ministers, monastics, aristocrats, shrine priests, and others, followed the instructions given by Xuanzang according to the account in Da Tang Da Ci'en si sanzang fashi zhuan to copy, receive, keep, recite and circulate the Dai hannya kyo with the aspiration of being reborn in one of the beneficial realms of the six realms. The Dai hannya kyō, in particular, was recited at the imperial palace and in sets of four, seven, ten, or fifteen temples during the Nara (710-794) and Heian periods. As of 771, the ten so-called great temples were: Daianji 大安寺, Yakushiji 薬師寺, Tōdaiji 東大寺, Kōfukuji 興福寺 (the so-called great four in Nara), Shin-Yakushiji 新藥師寺, Gangōji 元興寺, Hōryūji 法 隆寺 (Ikarugadera 斑鳩寺; the great seven temples in Nara), Gufukuji 弘福寺 (another name for Kawaradera 川原寺), Shitennōji 四天王寺 (Osaka), and Sūfukuji 崇福寺 (near Ōtsu, in Shiga prefecture). ${ }^{56}$ By the early tenth century, following the initial comprehensive inventory of 3,132 official deities (jinmyōcho $\bar{o}$ 神名帳) venerated at 2,861 official shrines listed in rolls 9-10 of Engishiki 延喜式 (Procedures of the Engi Era, 901-923, comp. 927; utilized after 967) ${ }^{57}$ Sūfukuji-and

55 Sagai, Shinbutsu shügō, 281-82. See also Keyworth, 'Apocryphal Chinese Books', 10-12. On the history of the development of jingüji, see Keyworth, 'Sustaining Tang Chinese Buddhist Rituals'; and Kochinski, 'Negotiations between the Kami and Buddha Realms'.

56 Shikō’s 志晃 (1662-1720) Jimon denki horoku 寺門傳記補録 [Supplemental Record of the Transmission Record of the Temple Gate Branch] 6, NBZ 787.86.146b quotes from Shoku Nibongi; partially translated in de Visser, Ancient Buddhism in Japan, 38-42. Genko shakusho 23 cited in the same section of Jimon denki horoku has a slightly different list and order, which may have been more authoritative: Daianji, Gangōji, Gufukuji (Kawaradera), Yakushiji [4], Shitennōji, Kōfukuji, Hōryūji, Sūfukuji, Tōdaiji, and Saidaiji 西大寺. On Kawaradera, see McCallum, Four Great Temples, 156-200.

57 The edition of Engishiki I consulted is from Kokushi taikei 国史大系 
Bonshakuji-along with Saidaiji 西大寺, Hongangōji 本元興寺 (Asukadera 飛鳥寺), [Tō 唐-] Shōdaiji 招提寺, Tōji, and Saiji 西寺 made up fifteen great temples. ${ }^{58}$

Less than forty years after Xuanzang and his team completed translating the Da bore jing in Tang China, in Japan emperor Gaozong 高宗 (628-683, r. 649-683) was believed to have elaborately celebrated the accomplishment and lavished Xuanzang with great honors by inaugurating the first festival to ritually read the $\mathrm{Da}$ bore jing (Dai Hannya kyō tendoku e or Hannya-e 般若会). One hundred monastics ritually read the Dai hannya kyō in the four great temples on 703.3.10; 600 monastics did the same in the palace on 725.1.17; and on 735.5.24, the Dai hannya kyo was ritually read to forestall natural disasters and calamities and protect the state and powerful clans. ${ }^{59}$ After an earthquake in 745 , the Dai hannya kyo was ritually read during the tenth month in all temples within the capital. ${ }^{60} \mathrm{It}$ was again ritually read for three days every month in 837 to protect against calamities that emanate from the sky (e.g., lightening or thunder) and earth (drought, illnesses, or plagues). It seems that adverse weather persisted because in 840 , the fifteen great temples were ordered to ritually read the Dai hannya kyo only during the day: nighttime recitations were thought to have caused adversity. ${ }^{61}$ In [Nihon] Sandai jitsuroku 三代実録 [True History of the Three

(Tokyo: Keizai zasshi-sha 経済雑誌社, 1897-1901), available online at: http://dl.ndl.go.jp/info:ndljp/pid/991103; accessed on May 22, 2018. The first ten rolls were translated by Bock, trans., Engishiki. Along with a digital edition of an edition printed in Kyoto in 1657, Bock's translation is searchable online at: https://jhti.berkeley.edu/Engi\%20Shiki\%20editions\%20and\%20copyrights.html, accessed on May 22, 2018. See also footnote 8.

58 Jimon denki horoku 6, NBZ 787.86.146b quotes from Genkō shakusho and Engishiki; partially translated in de Visser, Ancient Buddhism in Japan, 421-22. See also McCallum, Four Great Temples, 23-30.

59 Komine et al., 375, 379-81; de Visser, Ancient Buddhism in Japan, 493.

60 De Visser, Ancient Buddhism in Japan, 455-56; Komine et al., Hannyakyō taizen, 376-77.

61 De Visser, Ancient Buddhism in Japan, 304-06. 
Reigns (of emperors Seiwa 清和 [r. 858-876], Yōzei 陽成 [876-884], and Kōkō 光孝 [r. 884-887]) in Japan, comp. 901] 12 describes how a great fire that erupted in the capital on leap month (uruziki or jungetsu 閏月) 3.10 in 866 that spread to both the Shōran 翔鸞楼 and the Seihō 栖鳳楼 towers, which lay to the southwest and southeast of the Ōden gate 応天門, lasted twenty-two days. In order to assuage this calamity, twenty monks at Sūfukuji were required to ritually revolve read the entire Dai hannya kyō in seven days; 'secret rituals to the Four Heavenly Kings' (Shinō hibō 四王祕法) were performed at Bonshakuji by ten monks for seven days. ${ }^{62}$ We also know that veneration of the Dai hannya kyo did not abate over the centuries because by the tenth century Engishiki 21 states that every year on the first day of the fourth lunar month and again on thirtieth day of the eighth lunar month, a (presumably vegetarian) feast should be held at the fifteen great temples, and the first roll of the Dai hannya $k y o$ is read. And a repentance ritual was to be held at Süfukuji on the twelfth day of fourth lunar month that lasted for three days. ${ }^{63}$

A group of researchers in Japan and Bryan Lowe (Vanderbilt University) published a study in 2016 of seventy-six examples of the earliest Buddhist Japanese manuscripts with colophons. ${ }^{64}$ The earliest one dates to 686.5; the latest to 780.4.25. The first thing one notices about this selection is how prominent vowing the Dai hannya kyo was in Japan by the 720s: the earliest dated roll with a very long colophon is roll 24 with a date of 712.11.15. Twenty of the seventy-six examples from the annotated study and translation into modern Japanese of these colophons are to rolls from the Dai hannya kyo. The second most prominent text with colophons is Xuanzang's large translation in 100 rolls of the Yuqie shidi lun. Alternative evidence exists from Shiga prefecture, where Prince Nagaya 長屋王 (680-729) sponsored copying the Dai hannya kyō between 712-728, which appears to have been copied from scriptures once held in the Fujiwara capital 藤原京 (694-710). ${ }^{65}$ Abe Yasurō has written extensively on

\footnotetext{
62 De Visser, Ancient Buddhism in Japan, 304-06.

63 Cited in Jimon denki horoku 6, NBZ 787.86.146b-147a.

${ }^{64}$ Jōdai bunken o yomu kai, Jōdai shakyō shikigo.
} 
the notion of ritual offerings ( $k u y \bar{o})$ of either Xuanzang's translation of the Dai hannya kyō or sets of the canon as part of ritual activities increasingly bolstered by the clergy who instructed aristocrats with rituals about how to confer merit on or placating all manner of autochthonous and allochthonous deities.

These long colophons to eighth century rolls of the Dai hannya $k y \bar{a}$ are markedly different from the succinct examples we saw on rolls in either the twelfth century Matsuo shrine or Kongōji canons.

The first example I translate here is a colophon to roll 267 from Prince Nagaya's vowing project, dated 728.5.15: ${ }^{66}$

Jinki 5.5.15, disciple of the Buddha Prince Nagaya, with great sincerity makes this vow and offers a copy of a [complete] set of the Dai bannya kyo in 600 rolls. Line by line, every word of the columns in Chinese contain profound meaning when recited, reducing and ridding wickedness. It is an honor and exceedingly fortunate even to easily unroll and examine it. The good karma [from having it copied] is offered on behalf of my deceased parents with the following original vow: [they will be] reborn in Maitreya's (Tusita) Heaven where they can bow deeply to him, and amuse themselves in [his] pure abode. [If they listen to him with] reverential expressions, listen to [the teachings of] Amitābha buddha about the True Dharma, together they will realize unexcelled forbearance. The good roots [of copying this scripture] are dedicated to the current emperor and successive generations of emperors who will be enthroned for generations to come so the Three Jewels will be protected, the hundred gods will be guarded, and our current glorious ruler (emperor Shōmu 聖武天皇, r. 724-749) will achieve longevity of a thousand years [like those who ascend the Five Marchmounts in China]. As an immortal he will be reborn in the lofty heaven of a Pure Land, where he will achieve enlightenment on the path by cultivating the completion of meritorious acts. Conscious beings of the three realms who are born and die within the six realms, without vows [like the one]

\footnotetext{
65 Iwamoto, 'Nagaya No Ōkimi Hotsugankyō'.

${ }^{66}$ Jōdai bunken o yomu kai, Jōdai shakyō shikigo, 31-56.
} 
they cannot be fulfilled; their minds must be protected. Realizing [the law of] cause and effect, [and how it] affects everyone because of their sins and good deeds. The six perfections complete these [two types of] causes; the four kinds of wisdom cause the perfect effect. ${ }^{67}$

神龜五年, 歲次戊辰, 五月十五日, 佛弟子長王 至誠發願, 奉寫大般若經一部六百卷. 其經, 乃 行行列華文, 句句含深義. 讀誦者镯邪去悪, 披閲者納福臻榮. 以此善業, 奉資

登仙二尊神靈. 各隨本願, 往生上天, 頂礼弥勒, 遊 戲淨域, 面奉弥陁, 並聽聞正法, 俱悟无生忍. 又 以 此善根, 仰資 現御寓天皇并開闢以来代代 帝皇. 三寶覆護, 百靈影衛. 現在者, 爭榮於五获, 保壽於千龄; 登仙者, 生淨國, 昇天上. 聞法悟 道, 脩善成覺. 三界含識, 六趣禀靈, 无願不遂, 有心必 獲. 明矣因果, 達焉罪福, 六度因滿, 四智果圓.

Copied on Jinki 5.9.23 by Zhang Shangfu, Lesser Initial Rank, Lower Grade of the Bureau of Scattered Ranks (Sanniryō shō so-i $n o g e)^{68}$ 神龜五年歲次戊辰九月廿三日書生散位寮散位少初位下 張上福

First checked by Elder Yamaguchi Imiki, Legitimate person (ishi) without rank (mui) of the Ministry of Ceremonial Affairs (Shiki$b u-s h \bar{o})^{69}$ 初校生式部省位子无位山口忌寸人成

67 The six perfections are: giving, motivation, patience, energy, arresting malice, and wisdom. The four kinds of wisdom are: (1) knowledge of the one particular path to enlightenment; (2) knowledge of other paths to enlightenment; (3) knowledge that all phenomena are empty of characteristics; and (4) knowledge that phenomena are empty and remain distinct from one another.

68 This name, which I have given as a Chinese scholar's name, could also be a Korean name. According to Hirayama Asaji, 'Nagaya no ōkimi no Shōtoku taishi', 41-42, he could have been a scholar that Dōji met when he was studying in Tang China. The Shikibu-shō managed both the Daigakuryō 大学寮 (State or Imperial University) and the Sanni-ryō.

69 According to Nibon shoki 日本書紀 (720), a decree passed in 684 effectively 
Second check by Miyake no Shima-nushi, Legitimate person, without rank of the Ministry of Ceremonial Affairs 再校生式部省位 子无位三宅臣嶋主

Hadanotsune Imiki no Asaba, With Permission to Enter Lesser Palaces (uebito), without rank, government worker (banjō), Dyeing Paper Expert (Sōkō) of the Imperial Library $(Z u s h o r y \bar{o})^{70}$ 裝㣴圖書寮番上人无位秦常忌寸秋庭

Tsugida Akasome no Ishikane, Inspection Envoy (Kengyoshi) of the Saho Mansion (Sahogū), Junior Sixth Rank, Upper Grade (ju rokui no jō), Tenth Order of Merit (kun jūni tō) of Treasures for the Palace of the Upper Twelfth Rank 檢校使作寶宮判[官]從六 位上勲十二等次田赤染造石金

Narahisashokun, Inspection Envoy and Chief Manager (daisakan) from the Bureau of Yin-Yang Affairs (Onyōryō), Senior Eighth Rank, Upper Grade (shō hachi-i no jō), Tenth Order of Merit (kun jūni tō) 檢校使陰陽寮大属正八位上勲十二等楢佐諸君

Checked by Monk [Ki]ben from Yakushiji 檢校藥師寺僧[基]弁

Checked again by Dōji (d. 744) from Fujiwaradera ${ }^{71}$ 檢校藤原寺僧 道慈

Five sheets of asagami paper 用長麻紙伍張

Prince Nagaya was forced to commit suicide—his wife (Princess Kibi

standardized the aristocratic titles clan members could use into a set of 8 (yakusa no kabane 八色の姓): (1) Mahito 真; (2) Ason 朝臣; (3) Sukune 宿禰; (4) Imiki 忌寸; (5) Michinoshi 道師; (6) Omi 臣; (7) Muraji 連; and (8) Inagi 稲城. Rank 4 (Imiki) was primarily used to denote immigrants (see below), whereas rank 2 (Ason) was primarily awarded to Fujiwara 藤原 and later Taira 平氏 and Minamoto 源氏 clan members. Note the nearly-Daoist meanings for several of these rank titles.

70 The rank of uebito can also be read as Tenjo-bito 殿上人, or one who has permission to enter lesser palace halls, and banjö denotes a lower ranking official (kanjin 官人) who has permission to work within palace grounds on a daily basis.

71 Although it is not translated there, significant context for this colophon and possible attribution to Dōji is discussed in Wong, Buddhist Pilgrim-Monks as Agents of Cultural and Artistic Transmission, 100-08. 
Naishin no ō 吉備内親王, 686-729) and four children followed him in death-because of a power struggle at court with the descendants of Fujiwara no Fuhito 藤原不比等 (659-720). On 729.2.10, a minor official named Nakatomi no Azumahito 中臣東人 (the Nakatomi family of ritual specialists was related to the Fujiwara) accused Nagaya of plotting a rebellion against emperor Shōmu 聖武 (701756, r. 724-749): 'He is secretly studying the Left Way and seeks to overthrow the state'. ${ }^{72}$ The 'Left Way' that the prince was accused of practicing concerns his sütra copying project. The colophon may not provide any overt clues to the charge of 'black magic' against the prince, but it does illustrate three aspects of vowing sütras during the eighth century in East Asia. First, copying scriptures was an expensive affair that required significant investment from the state or wealthy patrons (paper, scribes, and so forth). Second, scriptures were vowed to memorialize one's ancestors. ${ }^{73}$ Finally, rebirth in Maitreya's Tusita heaven seems to have been the focus within Mahāyāna Buddhist cosmology prior to the arrival—or popularizing — of Amitābha.

Another roll of the Dai bannya kyō,232, dated 739.7.10, is translated as follows: ${ }^{74}$

Tenpyō 10.7.10, disciple of the Buddha Ishikawa no Asomi Toshitari, Lower Fifth rank, Twelfth Order of Merit, from Izumo no kuni, I bowed respectfully to the south, and to [the buddhas of the ten directions], all the bodhisattvas, sages, and others. I rely upon the profound ferry, with numerous blessings for peace and prosperity, relying on the mind of reality to look forward to the fruits of bodhi. Therefore I reverently [have] one [complete] set of the Dai bannya kyō copied to forever become the treasure of the monastery of Jodo-dera. The merit will celebrate good progress, the fate will be everlasting for kalpas to come as numerous as grains of sand [on the banks of the Ganges]. I further vow [this copy] to my entire family, seven generations of parents [and grandparents], and boundless, lim-

\footnotetext{
72 Ooms, Imperial Politics, 237.

73 Teiser, 'Ornamenting the Departed', 225-26.

${ }_{74}$ Jōdai bunken o yomu kai, Jōdai shakyō shikigo, 147-63.
} 
itless [numbers of] conscious beings form (bodies) so they can ride in the boat of prajñ $\bar{a}$ and ascend to the path of correct awareness.

維天平十一年, 歲次已卯, 七月辛印卯朔十日庚子, 佛弟子出雲國 守從五位下勲十二等石川朝臣年足, 稽首和南, 一切諸佛, 諸大菩薩, 并賢聖等. 託想玄津, 庶福於安樂; 歸心實 際, 冀果於菩提. 敬寫大般若經一部, 置淨土寺, 永 為寺寶. 以此功德, 慶善日新, 命緒将劫石俱延, 壽 笄與恒沙共遠. 又願: 內外眷属, 七代父母, 无邊无境, 有形含識, 並乗般若之舟, 咸登正覺之路.

The resolve in this colophon portrays the act of copying the Dai bannya kyō as an exceptional one, perhaps without equal. It is unclear if the author read the contents of this voluminous siutra, but it seems transparent that he must have been aware of the legendary endorsements of it by Xuanzang in Da Tang Da Ci'en si sanzang fashi zhuan.

The final example from eighth century Japan which I only partially translate- the names and titles are especially challenging-here is to roll 176. It is dated to the fifth month of 779, which makes it rather late in terms of the collection. It was kept at Mitsuki Hachimangū 御調八幡宮 (shrine, in Hiroshima 広島). ${ }^{75}$

As for the great vehicle of prajin $\bar{a}$, it is the liver and mind of all buddhas of the three ages, and the treasure storehouse of the bodhisattvas of the ten stages. ${ }^{76}$ Therefore, as for those who convert to

75 Jōdai bunken o yomu kai, Jōdai shakyō shikigo, 439-56. The portion that remains untranslated is: [親東父還乎感已] 盡曾笲之侍奉極仲 // [尼之孝養表] 為 子之至誠展物親之深 // [禮豈謂四虵] 侵命二鼠催年報運既窮 // [奄從去世] 孝誠 有䦕慈顏无感泉路轉 // [深終隔親見仰天] 伏地而雖悲歎都無 // [一益空] 沾領袖 唯有佛法必救恩虛 // [敬 以維] 寶龜十年歲次已未潤五月朔 // [癸丑母] 紀朝臣 多繼并男氏成女 // [秋穗等參人同志] 結言 奉寫大般若 // [大乗壹部陸佰卷以] 為遠代之法寶也 // [仰願以此功德先同] 奉資 先考之神 //

[路般若之舩淨於苦] 海速到極樂之寶 // [城大乗炬煥於問] 睢早登摩尼之玉殿 // [永覺三界之萝長息一如之床廣及有識] // [共出迷濱到涅槃岸].

${ }^{76}$ The ten stages of the Prajñāpāramitā texts are: (1) dry wisdom (worldly 
Buddhism, who will not [be able to] ward off calamities and enjoy ease and comfort? Those who obey [the teachings], how could they not sever confusion and realize reality? I prostrate to filial son Saka no Ue no Imiki no Ujitsune, (daughter) Akihoto, deceased father Ideha, Lower Fifth rank, Fourth Order of Merit, Saka no Ue Imiki no Iwatate, daifu (a title, not a doctor) with great kindness as bountiful as Mount Sumeru is lofty, whose compassion is as deep as the great ocean. He has lived many lives, his body smashed and his destiny abandoned. He must be rewarded because he deserves longevity from Queen Mother [of the West]...

夫以般若大乗者, 斯乃三世諸佛之肝

心, 十地菩薩之寶藏. 然則, 帊依者, 誰不

消灾納福; 隨順者, 豈无斷惑證真? 伏

惟: 為孝子坂上忌寸氏成秋穗等, 慈

先考故出羽介從五位下勲四坂上

忌寸石楯大夫之厚恩, 撫育之慈高踰

須弥, 眅護之悲深過大海. 經生累劫, 砕

身捨命, 何得報哉? 方欲西母長壽, 晉於...

These colophons demonstrate two points that may very well have been known to Hata no Chikatō and Yorichika, and the scribes who copied the scriptures for Nanatsudera and other similar projects in twelfth century Japan. First, one imagines that when monastics, aristocrats, or even shrine priests read, recited, or copied Buddhist manuscripts, they were aware that '[c]opying was not a matter of simply duplicating a text. Transcribing a sacred text was one of the most potent magico-spiritual exercises: it would activate and increase the power of its words, akin to a greatly multiplied power of spells'. ${ }^{77}$

wisdom); (2) knowledge of the four wholesome roots that give rise to awareness of one's nature; (3) awareness of the eight tolerances; (4) freedom from wrong views; (5) freedom from the first six of the nine delusions; (6) freedom from desire; (7) stage of complete discernment; (8) stage of a pratyekabuddha (enlightenment through one's own karma); (9) a bodhisattva; and (10) a buddha.

77 Ooms, Imperial Politics, 240. 
Second, because so many especially Mahāyāna scriptures instruct the reader about the efficacy of the act of copying-and perhaps even proofreading-scriptures, performing these 'nonmeditational' or 'meritorious' acts (kuśalena karmaña) was almost certainly viewed as an integral practice for the devoted. How much more so the case if one is sponsoring or actually copying the largest Buddhist scripture in Chinese?

\section{Manuscripts and Fragments of the Da Bore Jing from Dunhuang}

There are certainly copious examples of Buddhist texts with long colophons from Dunhuang to match these examples to several rolls of the Dai hannya kyo from eighth century Japan. But, to the best of my knowledge, of the more than 700 separate manuscripts or manuscript fragments just catalogued from the Stein collection or those carefully studied by Ikeda On, Ji Xianlin, or Huang Zheng, none of the colophons to the Da bore jing are either long or particularly revealing in terms of information about donors, scribes, or even ritual readings of this text in medieval China. ${ }^{78}$ There is, however, intriguing information from mostly several examples to deduce that possessing a complete copy of this seminal text was important for monastics who kept libraries at temples within the Mogao grottoes complex during the ninth century.

As we saw with the Matsuo shrine, Nanatsudera, and Kongō manuscripts discussed above, most of the examples of rolls of the Da bore jing were checked at least once or twice. Roll 216, for example, which is S. 1594, informs us that the scribe was named Huize, and it was checked once by Lingxiu and again by Yiquan: 惠澤 靈秀一校第二校義泉. ${ }^{79}$

78 Giles, 'Dated Chinese Manuscripts in the Stein Collection, Ii'; Giles, 'Dated Chinese Manuscripts in the Stein Collection, Iii'; Giles, 'Dated Chinese Manuscripts in the Stein Collection, I'; Giles, 'Dated Manuscripts in the Stein Collection Iv'; Giles, 'Dated Chinese Manuscripts in the Stein Collection Vi'; Ikeda, Shabon; Ji, ed., Dunbuangxue Dacidian; Huang and Wu, Dunbuang yuanwen ji.

79 Ikeda, Shahon, 363. Note 221 in Giles, Descriptive Catalogue, 6. 
The roll is undated. Roll 232 (S. 3841) was collated by Huaihui: 懷 惠勘. ${ }^{80}$ Roll 398 (S. 1973) may provide evidence of ritual reading of

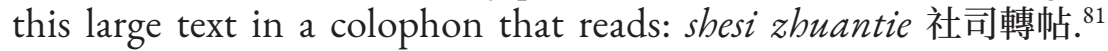
Lionel Giles rightly, I think, carefully notes when taboo characters employed during the reign of Empress Wu Zetian 武則天 (624-705; r. 690-705) are found. But what stands out most prominently from these short colophons are instances in which black stamps-similar to the six-line stamp on every tenth and eleventh roll from Nanatsudera - with the names of monastic libraries were added to these rolls. S. 296, which is roll 103, has a prominent stamp that reads: Sanjiesi zangjing 三界寺藏經. ${ }^{82}$ There is also the impression of a seal in red ink with the name of another monastic library: Baoensi zangjing yin 報恩寺藏經. The same seal can be found on rolls 141 (S. 2764) and 326 (S. 1566). ${ }^{83}$ The same seal and stamp on roll 103 can be found on roll 343 (S. 3788) and 440 (S. 1587). ${ }^{84}$ And there is a note to roll 23 (S. 3621) that evokes, however dimly, one aspect of the five practices of the preacher of the buddhadbarma extolled in Mahāyāna literature and ascribed to Xuanzang by Huili and Yancong. The note reads: biqiu Jiezang xie biqiu Huisu shouchi 比丘戒藏寫惠素受持. The presence of the characters san en 三恩 below the title on the outside of the roll may indicate that this roll belonged to the third bundle from the library of Baoensi. ${ }^{85}$ These are too few examples to infer any pattern of either ritual reading or study to correspond to what we can safely presume transpired with the Dai hannya kyō from Nanatsudera and Matsuo shrine. We know very little for certain about who closed the library cave of the Mogao grottoes or when or why or where the many, sometimes very old copies of similar Buddhist scriptures came from (possibly from Khotan [Yutian 于闐, Hetian 和田]) or who donated or collected

\footnotetext{
80 Note 248 in Giles, Descriptive Catalogue, 6.

81 Note 410 in Giles, Descriptive Catalogue, 10.

82 Ikeda, Shabon, 353. Note 116 in Giles, Descriptive Catalogue, 3.

83 Notes 158 and 360 in Giles, Descriptive Catalogue, 4, 9.

84 Notes 360 and 443 in Giles, Descriptive Catalogue, 9, 11.

85 Note 32 in Giles, Descriptive Catalogue, 1-2.
} 
them (likely Daozhen 道真 from the Three Realms monastery [Sanjiesi]). ${ }^{86}$ Furthermore, it is difficult to speculate about why this library contained manuscripts with a span of about 500 years (S. 996: dated 479.10.28 through S. 4601: dated 985.11.28). ${ }^{87}$

There are two additional colophons from Dunhuang that I think are particularly helpful in terms of ascertaining precedents for either the long colophons we saw from eighth century Japan or the steadfast attention to the Dai hannya kyō in historical records and from colophons from Matsuo shrine, Nanatsudera, or even Kongojji. The first one is a seventh century colophon on P. 2106, roll 8 of the 100 roll commentary to part of what is contained in the Da bore jing, $\mathrm{Da}$ zhidu lun 大智度論 (*Mahāprajñāpāramitopadeśa, $Z$ no. 668, T no. 1509). ${ }^{88}$ This colophon is unsigned, and translated as follows:

In the past, when the bodhisattva of the Himālayas [vowed to] sacrifice his body to [hear the full] eight verses, Great teacher of the Fragrant City broke his skeleton apart with a single utterance. ${ }^{89} \mathrm{I}$

86 Hansen, 'Tribute Trade with Khotan'. Hansen follows Rong, 'The Nature of the Dunhuang Library Cave'. See also Rong, Eighteen Lectures on Dunbuang, 5, 109-36.

87 S. 996 is roll six of the Abhidharma-sära-prakìnnaka-śāstra (Za apitan xin lun 雜阿毘昙心論, $Z$ no. 1080, $T$ no. 1552) translated in 434 by Sanghavarman 僧伽跋摩; S. 4601 is the first roll of Xianjie qian foming jing 賢劫千佛經 ( $Z$ no. 465, $T$ no. 447), unknown translation but probably Liang dynasty (502-557). Ikeda On's study shows that 479 is not the earliest dated Buddhist colophon from Dunhuang; cf. Giles, Descriptive Catalogue, x, 127, note 4335; Ikeda, Shahon, 92, note 101. Also cited in Lancaster, Korean Buddhist Canon, 223. For S. 4601 see Giles, 'Dated Chinese Manuscripts', 169; Ikeda, Shabon, 528.

88 Ikeda, Shabon, 255, note 725. The Chinese text reads: 昔雪山菩薩, 八字捨 身, 香城大師, 一言析骨. 况我凡愚, 而不迴向. 佛弟子田豐, 躬率己財, 兼勸有心. 仰為: 皇帝文武百僚、七世父母、過見師尊、及法界眾生, 敬寫一切經論, 願共成佛.

89 According to the Da banniepan jing 大般涅槃經 (Mahāparinirvāna-sütra), $T$ no. 374, 12: 375a27, in a previous lifetime the Buddha was a bodhisattva living in the Himālayas when Indra spoke a verse to him from the räkșasas: 'All phenomena are impermanent, which is the Dharma of arising and 
am so much more ordinary and foolish than [the bodhisattva] was, and I have not yet dedicated the merit [of this copy]. Disciple of the Buddha Tian Feng is personally wealthy, mindful of this advice. I reverently dedicate the copying of all the scriptures and commentaries to the emperor, one hundred civil and military ministers, seven generations of [my] parents [and grandparents], and sentient beings [so they] will [meet] the venerable Thus Come One (Tathāgata) and become buddhas.

Here we learn of a wealthy lay Buddhist who had either read or heard from a teacher about the contents of another part of the Da zhidu lun and the Da banniepan jing 大般涅槃經 ([Mahāyāna] Mahāparinirvāna-sütra, $Z$ no. $135, T$ no. 374). And Tian Feng may have vowed an entire set of all the scriptures and commentaries. It also may be instructive from this earlier example that it appears the donor knew quite a bit about Mahāyāna Buddhist literature. Furthermore, the Da zhidu lun is a commentary to a text already known in the mid-seventh century across East Asia as the Dapin bore jing 大品般若 經 (Daiban hannya kyō) or the Perfection of Wisdom in many verses.

The second example is from the first roll of the Da bore jing from Dunhuang. This roll also has a black stamp like the one we saw on roll 103. S. 3755 is a long roll, which Giles measured to at 26.5 feet (8.07 meters).${ }^{90}$ It is not the stamp which interests me, but the two prefaces that can be found before the first chapter of the Da bore jing commences. The only other manuscript where I have seen these two prefaces is on the Nanatsudera edition of Xuanzang's translation of the *Abhidharmamahāvibhāsạ̄-śāstra [Apidamo dapiposha lun

ceasing; arising and ceasing, already extinguished, the cessation of extinction is bliss'諸行無常, 是生滅去; 生滅滅已, 寂滅為樂. The bodhisattva only heard half of the verse. In order to hear the second half from the räkșasas, he vowed to sacrifice his body. He did not have to sacrifice himself to hear the second half. The Fragrant City refers to a buddha-land where the bodhisattva Dharmodgara 曇無 竭 resides; the bodhisattva Sadāpralāpa 常啼 makes his way to the city to learn the teaching from this bodhisattva. Cf. T no. 1509, 25: 734a-b.

90 Note 4 in Giles, Descriptive Catalogue, 1. 
阿毘達磨大毘婆沙論, Compendium of the 500 Arhats, $Z$ no. 1072, $T$ no. 1545]. These two manuscripts, one from probably ninth century Dunhuang and the other from late twelfth century Japan, start with two exemplary prefaces that are supposed to have accompanied all the translations completed by Xuanzang and his team in Tang dynasty [manuscript] Buddhist canons. Apparently at Xuanzang's request, two stone steles or tablets ( $b e i$ 碑) at Dayan ta 大雁塔 in Xi'an were carved in 653, when emperor Gaozong 高宗 (628-683, r. 649-683) had a five-story stūpa erected on the grounds of the temple he had converted into Da Ci'en si 大慈恩寺 and dedicated to his deceased mother, empress Wende shunsheng 文德順聖皇后 or Zhangsun 長孫 皇后 (601-636), in 648. The two steles consist of a preface that his father, emperor Taizong 太宗 (598-649, r. 626-649), wrote in 648 called Da Tang sanzang Shengjiao $x u$ 大唐三藏聖教序 [Preface to the Sacred Teachings (translated by) Trepitaka of the Great Tang] to accompany all of the new translations that Xuanzang and his team completed after the Yogācārabhūmi-sástra was complete; Gaozong's own Da Tang Huangdi shu sanzang Shengjiao xuji 大唐皇帝述三藏 聖教序記 [Commemoration of the Preface written by the Emperor of the Great Tang (dynasty) to the Sacred Teachings (translated by) Trepitaka (Xuanzang)], written in 652, is the second preface carved for Dayan ta and written out in kaishu 楷書 style by imperial secretary Chu Suiliang 褚遂良 (596-658). ${ }^{91}$ A monk by the name

91 Wong, 'The Making of a Saint', 47-49, see esp. figures 1-1a. Wu Jiang cites the thirteenth century Fozu tongji 佛祖統紀 [Historical Chronicle of the (History of the) Buddhas and Patriarchs], T no. 2035, 49: 39.366b4-19, which says that these two prefaces were 'ordered to be put at the beginning of the canon'; see Wu, ‘Cult of the Book’, 47-48. The text reads: 因勅有司, 寫新譯經論, 頒賜九道 總管(時分天下為九道). 御製《大唐三藏聖教序》, 以冠其首(今時石本行, 其文首 云, ‘蓋聞二儀有像, 顯覆載以含生.' 即此序也). 詔皇太子撰《菩薩藏經後序》(三 序具在藏經之前). 上自是平章法義, 不輟於口. I have not explored what Zhipan 志磐 (1220-1275) may mean by 'what the crown prince composed as an afterward to a collection of bodhisattva scriptures' [詔皇太子撰菩薩藏經後序. But my reading both of the translations of the two prefaces and their purpose in the mid-seventh century follows Wong, rather than Wu. It does appear that Zhipan 
of Huairen 懷仁 from the temple where Xuanzang commenced his translation activities with support from Taizong in 646, Hongfusi 弘福寺, had these prefaces newly engraved in 672 using the style of Wang Xizhi 王羲之 (303-361), who was well known to be one of Taizong's favorite calligraphers. ${ }^{92}$ These prefaces survive on two steles in the city of Xi'an and in fragments from Dunhuang. ${ }^{93}$ They do not accompany any of Xuanzang's translations in printed editions of the Buddhist canon of Chinese. They are, however, recorded in Da Tang Da Ci'en si sanzang fashi zhuan, in Daoxuan's Guang Hongming ji and $X u$ Gaoseng zhuan, and glosses to odd terms are provided in Huilin's 慧琳 (737-820) Yiqiejing yinyi 一切經音義 [Glossary to all the jing (in the Buddhist canon), $T$ no. 2128, comp. 807]. ${ }^{94}$ The text is

may have believed there was a canon that either Taizong or Gaozong commissioned, but we see no evidence of this here.

92 Wong, 'The Making of a Saint', 48.

93 S. nos. 4818 and 4612, respectively; see Giles, Descriptive Catalogue, 1. They are understood to have been erected at Big Goose Pagoda (Dayan ta 大雁 塔) in 653; see Sheng, 'Development of Chinese Calligraphy', 65. Closer confirmation comes from Xuanyi’s 玄逸 (d.u.) Da Tang Kaiyuan Shijiao guangpin lizhang 大唐開元釋教廣品歷章 [Complete sections and extensive listing (of the contents of) the Great Tang Kaiyuan era Buddhist (canon)], of which only rolls 5-10 and 12-20 are available in the Jin dynasty (1115-1234) printed Buddhist canon: $A$ no. 1276, 98 in CBETA, which reproduces the extant vols. of the Jin canon from Zhonghua dazang jing: Hanwen bufen 中華大藏經:漢文部分, ed. Zhonghua dazang jing bianji ju; this edition from 1256 was kept at the Da Baoji si 大寶積寺 in Beijing; only 555 rolls of the Jin canon are extant. See Zhang, 'Unforgettable Enterprise', 14, notes 2-4.

On Xuanyi, see Song gaoseng zhuan 宋高僧傳 [Biographies of Eminent Monks, (compiled under the) Song (dynasty), 988], T no. 2061, 50: 734a23.

94 Da Tang Da Ci'ensi sanzang fashi zhuan, T no. 2053, 50: 7.256a28-c24 and $T$ no. 2053, 50: 7.257aa25-c7, translated in Li, Tripitaka Master, 196-99, 203-06. Cf. Guang Hongming ji, $T$ no. 2103, 52: 22.258a270c16 and $T$ no. 2103, 52: 22.259a11-b17; Xu Gaoseng zhuan, T no. 2060, 50: 4.456a6-c1 and $T$ no. 2060, 50: 4.456c25-457b5; and Yiqiejing yinyi, T no. 2123, 54: 1.4.312a11$313 c 5$. 
not reproduced in Da Tang gu sanzang Xuanzang fashi xingzhuang 大唐故三藏玄裝法師行狀 [Report on the career of Trepitaka Xuanzang of the Great Tang, T no. 2052, comp. ca 664 by Mingxiang 冥祥], but it does speak of the 780 words in Taizong's preface and 570 in Gaozong's. ${ }^{95}$ Nor is the latter text included in Zhenyuan lu.

The first roll with the two extra prefaces from Nanatsudera is undated, but we know that it was copied by a monk named Sōken 相 兼, sponsored by the abbot of Atsuta 熱田 jingüji, and the work was checked by Eishun; roll 61 is dated 1177.4.10. ${ }^{96}$ Despite the fact that we know the compilers of the Nanatsudera [and Matsuo] canons possessed copies of the first Chinese Buddhist canon printed in 983, I believe that these two prefaces corroborate how much attention was awarded to preserving and bolstering the cultural memory of not only considerable patronage of the Buddhist church by early Tang rulers but also the state-sponsored translation projects, the most famous of which was the team led by Xuanzang. There may also be slight textual variations between these two prefaces that I have not yet awarded enough attention to. But I am certain that the reduplication of these two prefaces on the Nanatsudera edition of the Abidatsumadaibibasharon attests to the fact that copying from Tang exemplars was the predilection in twelfth century Japan.

\section{Conclusion: Prajūāpāramitā Texts in the Da Bore Jing/Dai Hannya Kyō}

Written on roll 522 of the Dai hannya kyo from the Matsuo shrine canon, which I mentioned before only in passing, are large characters that read: Dai hannya ya 大般若也. Based upon a separate study of Yijing's 義淨 (635-713) translation of the Suvarnabhāsottama-sūtra (Jin'guangming zuishengwang jing 金光明最勝王經, $Z$ no. $158, T$ no. 665) in the Matsuo shrine canon, it recently came to my attention that certain rolls have colophons to indicate how to ritually read

\footnotetext{
95 T no. 2052, 50: 218a24-0b3.

96 Nanatsudera issaikyō hozonkai, Nanatsudera issaikyō mokuroku, 96-99.
} 
them. Rolls nine and ten of the Konkōmyō saishōō kyō from Matsuo, for example, have Matsuno'o issaikyō 松尾一切經 written on the back of each roll in intervals to indicate where the reader should stop rolling (or unrolling) in order to ritually read the text. The large characters dai hannya ya on roll 522 of the Dai hannya kyō were probably written to indicate that a ritual reading was completed. These examples from the Matsuo shrine canon lead me to ask a question about colophons to rolls of the Da bore jing from Dunhuang or the Dai hannya kyō from Nanatsudera, Kongōji, Matsuo or almost any other manuscript Mahāyāna Buddhist text in Chinese: did the scribes, donors, or sponsors intend to have colophons written on specific rolls because they either had read that particular roll or chapter and considered it important or perhaps even salvific? In other words, do colophons tell us anything about which parts of particular texts may have been interesting-intellectually, spiritually, or ritually-to those who produced or used them? Did Fujiwara no Kiyohara 藤原 清衡 (1056-1128) who sponsored a manuscript canon for Chūsonji 中尊寺 in Ōshū Hiraizumi 奥州平泉 copied in alternating gold and silver ink on indigo paper between 1108-1117, consider which parts of texts-such as rolls 345 or 460 of the Dai hannya kyo-should be copied in such an expensive medium? ${ }^{97}$

The six-line stamp on every tenth and eleventh roll of the Dai bannya kyō from Nanatsudera probably does not suggest much more than tendoku was [often] performed with these manuscripts. In order to determine-or speculate-about the rolls with particular colophons from Dunhuang or ancient or medieval Japan, one would have to know something about the contents of this colossal text. Thankfully, Edward Conze (1904-1979), Hikata Ryūshō 干湆竜 祥 (1892-1991), and others, have produced comparative studies of Prajūāpāramitā literature in Sanskrit, Chinese, Tibetan, Mongolian, and so forth. Let me begin with a few rather basic points about the Da bore jing. The 600 rolls comprise a text which presents sixteen

97 Ochiai et al., 'Découverte de manuscrits', 370-71. See rolls 345 and 460 in and other examples Nara National Museum, Special Exbibit, notes 39-40, and $70-71$. 
assemblies (bui 會)—'sermons' or 'meetings' — understood to have taken place at four key locations:

1. Assemblies 1-6 (1: rolls $1-400 ; 2-6$ : rolls 401-573), and 15 (rolls 591-592) take place at Vulture Peak (Gṛdhrakūṭa 霊熟 山) in the city of Rājagṛha 王舎城.

2. Nos. 7-9 (rolls 574-577) and 11-14 (rolls 579-590) take place in Anāthapiṇdada's 給孤獨 (Sudatta 須達) park in Śrāvastī 舎衛城: Jetavanavihāra 祇園精舎.

3. No. 10 (rolls 578) takes place in the abode of Paranirmitavaśavartin gods 他化自在天.

4. No. 16 (593-600) is set near Snowy Heron Pond in the Bamboo park near Rājagṛha (Karaṇda-veṇuvana). ${ }^{98}$

Taishō vol. 5 (pp. 1-1074) has rolls 1-200; vol. 6 (pp. 1-1073) has rolls 200-400; vol. 7 (pp. 1-1100) with rolls 400-600.

The first assembly-in 400 rolls in over 2,000 pages in the Taishō edition-consists of probably a much longer version of the Satasabāsrika (Perfection of Wisdom in 100,000 lines), which is otherwise only translated into Tibetan (some ninth century examples from Dunhuang). ${ }^{99}$ The second assembly is the Pañcavimsatisābasrika (Perfection of Wisdom in 25,000 lines), which covers rolls 401-478 in the Da bore jing. T nos. 221, 222, and 223 also translate versions of this sütra. ${ }^{100}$ The third assembly is a slightly shorter version of the Perfection of Wisdom in 25,000 lines in only 18,000 lines (Astadaśasābasrikā), which, like the first 400 rolls, is not translated into Chinese elsewhere. Only because Xuanzang and his team translated both the Perfection of Wisdom in 25,000 and 18,000

98 Conze, Prajñāpāramitā Literature, 28; de Visser, Ancient Buddhism in Japan, 492; Hikata, Suvikrāntavikrāmi-Pariprcchā-Prajñāpāramitā-Sūtra, Table II.

99 Conze, Prajñāpāramitā Literature, 39; van Schaik, 'The Uses of Implements', 235-36. Each of the seventy-nine chapters in Chinese is outlined with page numbers to the Taishō edition in Komine et al., Hannyakyō taizen, 196-99.

100 Komine et al., Hannyakyō taizen, 37-39; Conze, Prajñāpāramitā Literature, 41 . 
lines-rolls 488-537-are both versions known in Chinese as the Dapin jing or Daibankyo. ${ }^{101}$ The fourth assembly, which consists of rolls 538-555, is the famous Astasāhasrikā (Perfection of Wisdom in 8,000 lines). $T$ nos. 224, 225, 226, 227, and 228 also translate this text. The Astasābasrika is known in East Asia as the Perfection of Wisdom scripture with Fewer lines (Xiaopin bore jing, Shōban hannyakyō 小 品般若經). It may be instructive that Conze thought this version corresponds closely with extant Sanskrit editions. ${ }^{102}$ The fifth assembly is earlier version of the Astasāhasrikā; the Fayuan zhulin says this edition was translated from a version with 4,000 slokas. ${ }^{103}$ The sixth assembly, which covers rolls 566-573, retranslates part of the same text as in $T$ no. 231: the ${ }^{*}$ Devarājapravara-prajñ̄apāramita-sütra, a part of the Suvikrāntavikrāmi-pariprccha-prajñāpāramitā-nirdeśa or Sāddhadvisāhasrikā (The Questions of Suvikrāntavikrāmin). ${ }^{104}$ The sixteenth assembly, which is rolls 593-600, consists of the main portion of a this text, available only in Hikata's 1958 study. The seventh assembly is Saptasatika (Perfection of Wisdom in 700 lines), rolls 574-575, which was also translated in $T$ nos. 232 and 233. The eighth assembly, roll 576, is another retranslation, in this case of the Nàgaśrīpāriprcchā-sūtra (Rushou pusa wushang qingjing fenwei jing 濡首菩薩無上淸淨分衞經, $Z$ no. 14). The ninth assembly, roll 577, is another celebrated Prajñāparamitā text, the Vajracchedikā (Jin'gang jing 金剛經). T nos. 235, 236, 237, 238, and 239 also translate the Diamond Sütra. ${ }^{105}$ Roll 578 is the tenth assembly and

101 There are eighty-five chapters in the second assembly and only thirty-one in the third: see Komine et al., Hannyakyō taizen, 196-99. For a comparative chapter list in English, see Conze, Prajñāpāramitā Literature, 45-50.

102 Conze, Prajñāpāramitā Literature, 54-55. For a comparison between the contents of the Pañcavimśatisābasrikā and the Asțasābasrikā, or Dapin and Xiaopin editions, see Komine et al., Hannyakyō taizen, 40-41.

${ }^{103}$ Fayuan zhulin, T no. 2122, 53: 100.1024b18-1025a16.

${ }^{104}$ Komine et al., Hannyakyō taizen, 43-45. Conze, Prajñāpāramitā Literature, 60-62. See also note 132 in Herrmann-Pfandt, Die Lhan Kar Ma Ein Früher Katalog, 73.

105 Conze, Prajñāpāramitā Literature, 64-70. 
is the Adbyardhaśatikā or Prajñāpāramitā-naya-satapañcaśatikā (Liqu jing 理趣經 [Sütra that Transcends the Principle]; 150 lines). $T$ nos. 240-244 translate this later Perfection of Wisdom treatise. ${ }^{106}$ Assemblies 11-15, which comprise rolls 579-592, are only available elsewhere in the five perfections outlined in the Tibetan Arya-pañcapāramitānirdeśa-nāmamahāyāna-sütra ("phags-pa pha-rol-tu phyinpa lina bstan-pa, T no. 221). ${ }^{107}$

I provide this overview of the contents of the Da bore jing because I wonder if, for example, roll 522 from Matsuo with the indication that it was ritually read could be significant because we know this is a roll from the Astadaśasāhasrikāe? Or that several of the rolls that came from Shitennōji correspond to the Astasāhasrikā? When we acknowledge that the majority of the colophons under review in this paper to the Da bore jing from twelfth or eighth century Japan and Dunhuang are to rolls from the Perfection of Wisdom in perhaps 200,000 lines, then it appears the task ahead is to read these rolls to determine if the donors, scribes, or sponsors were thinking of particular lines of text within each roll. I suspect, however, that what was foremost in the minds of these devotees was the image of Xuanzang himself evoking the words:

It is recorded in the sutra itself that in this country there will be people taking delight in Mahayana teachings. All kings, ministers, and followers of the four groups who copy, receive, and keep it, as well as recite and circulate it will be reborn in the heavens and obtain ultimate emancipation. Since there is such a passage, we must not keep silent about it.

106 Conze, Prajñāpāramitā Literature, 78-79.

107 Note 104 in Herrmann-Pfandt, Die Lhan Kar Ma Ein Früher Katalog, 59-60. 


\section{Bibliography}

Abbreviations

$J$

NBZ

S.

T

$Z$
P. Pelliot collection of Chinese manuscripts from

Mingban Jiaxing dazang jing: Jingshan zangban 明版 嘉興大藏經: 徑山藏版 [Ming dynasty printed Jiaxing Chinese Buddhist Canon; Mount Jing edition]. See Bibliography, Primary Sources, Mingban Jiaxing dazang jing.

Dai Nibon Bukkyōzensho 大日本佛教全書 [Complete Buddhist Works of Japan]. [Complete Buddhist Works of Japan]. See Bibliography, Primary Sources, Dai Nibon Bukkyōzensho. Dunhuang. See Bibliography, Secondary Sources, Pelliot collection of Chinese manuscripts from Dunhuang.

S. Stein collection of Chinese manuscripts from Dunhuang. See Bibliography, Secondary Sources, Stein collection of Chinese manuscripts from Dunhuang. Taishō shinshū daizōkyō 大正新脩大藏經 [Revised version of the East Asian Buddhist Canon, compiled during the Taishō era]. See Bibliography, Secondary Sources, Takakusu and Watanabe, eds. Zhenyuan xinding shijiao mulu 貞元新定釋教目錄 [Newly Revised Catalogue of Buddhist Scriptures made during the Zhenyuan-era, T no. 2157]. See Bibliography, Primary Sources, Zhenyuan xinding shijiao mulu.

Titles in Japanese and [reconstructed] Sanskrit in the Taishō canon follow Paul Demiéville et al., Répertoire du Canon Bouddbique Sino-Japonais, Édition de Taishō (Taishō Shinshū Daizōkyō) : [Fascicule Annexe du Hōbōgirin], Éd. rev. et augm. ed. (Paris: Librairie d'Amerique et d'Orient, 1978) and Lewis R. Lancaster and Sung-bae Park, eds., The Korean Buddbist Canon: A Descriptive Catalogue (Berkeley: University of California Press, 1979). 


\section{Primary Sources}

Da bore boluomiduo jing 大般若波羅蜜多經 [Skt.

${ }^{*}$ Mahāprajūnāpäramitā-sūtra]. 600 juan. Xuanzang 玄牀 (602664). T no. 220, vols. 5-7.

Da banniepan jing 大般涅槃經 [Skt. Mahāparinirvāna-sütra]. 40 juan. Trans. Tanwuchen 昙無識 (Dharmakșema, 385-433). T no. 374, vol. 12.

Da Tang Da Ci'en si sanzang fashi zhuan 大唐大慈恩寺三藏法師傳 [Biography of the Tripitaka dharma master of the Great Cien Monastery of the Great Tang (Dynasty)]. 10 juan. By Huili 慧立 (615-675?) and Yancong 彥悰 (ca. 650-688). T no. 2053, vol. 50.

Fayuan zhulin 法苑珠林 [Jade Forest in the Dharma Garden]. 100 juan. Comp. Daoshi 道世 (d. 683). T no. 2122, vol. 53. Fozu tongji 佛祖統紀 [General Account of the Buddha and

Patriarchs]. 54 juan. Comp. Zhipan 志磐 (ca. 1220-1275). T no. 2035, vol. 49.

Guang Hongming ji 廣弘明集 [Extended Collection for Propagating and Elucidating Buddhism]. 30 juan. Comp. Daoxuan 道宣 (596-667). T no. 2103, vol. 52.

Jimon denki horoku 寺門傳記補録 [Supplemental Record of the Transmission Record of the Temple Gate Branch]. By Shikō 志晃 (1662-1720). NBZ vol. 127.

Miaofa lianbua jing xuanyi 妙法蓮華經玄義 [Mysterious Meanings of the Lotus Sutra]. 10 juan. By Zhiyi 智顗 (538-597). T no. 1716, vol. 33.

Song Gaoseng zhuan 宋高僧傳 [Biographies of Eminent Monks, (compiled under the) Song (dynasty)]. 30 juan. Completed by Zanning 贊寧 (919-1001) et al. in 988. T no. 2061, vol. 50.

Suxidi jieluo jing 蘇悉地羯羅經 [Skt. Susiddhi-kara-maha-tantrasādhanôpāyika-patala]. 3 juan. Trans. Śubhakarasimha 輸波迦羅 (善無畏, 637-735). T no. 893a, vol. 18.

Xu Zhenyuan Shijiaolu 續貞元釋教錄 [Continuation of the Zhenyuan Shijiao Lu (Catalogue of the Buddhist Teachings compiled under the Zhenyuan Era)]. 1 juan. Comp. Heng'an 恆 安 (937-975) between 763-764. T no. 2158, vol. 55. 
Za apitan xin lun 雜阿毘昙心論 [Skt. Abhidharma-sāra-prakirnakaśāstra]. 11 juan. Trans. Sanghavarman 僧伽咙摩 in 434. Tno. 1552, vol. 28; $Z$ no. 1080.

Zhenyuan xinding shijiao mulu 貞元新定釋教目錄 [Newly Revised Catalogue of Buddhist Scriptures made during the Zhenyuanera, $T$ no. 2157]. Comp. by Yuanzhao 圓照 (d.u.), ca. 799 or 800. Nos. follow the Nanatsudera MS in Miyabayashi Akihiko 宮林昭彦 and Ochiai Toshinori 落合俊典, 'Zhenyuan xinding Shijiao Mulu Juandi 貞元新定釋教目錄 29 30', In Chügoku nihon kyōten shōsho mokuroku and Nihon genson hasshu issaikyō Taishō mokuroku tsuke Tonkō Bukkyō bunken.

\section{Secondary Sources}

Abé, Ryūichi. The Weaving of Mantra: Kükai and the Construction of Esoteric Buddhist Discourse. New York: Columbia University Press, 1999.

Abe Yasurō 阿部泰郎. Chūsei Nihon no shūkyō tekusuto taikei 中世日 本宗教テクスト体系 [The System of Medieval Japanese Religious Texts]. Nagoya: Nagoya daigaku shuppankai 名古屋大學出版社, 2013.

Adolphson, Mikael. The Gates of Power: Monks, Courtiers, and Warriors in Premodern Japan. Honolulu: University of Hawai' $i$ Press, 2000.

Akao Eikei 赤尾榮慶. 'Koshakyō shi kara mita nanatsudera issaikyō: Shoshigaku teki Apurocchi o chūshin ni’古寫經史から見た七寺 一切經一書誌學的アプローチを中心に [The Nanatsudera Canon from the perspective of manuscript traditions]. In Chügoku Nibon Senjutsu Kyōten 中國日本撰述經典 [Scriptures and Commentaries Composed in China and Japan], edited by Ochiai Toshinori 落合俊典, Okabe Kazuo 岡部和雄, Sueki Fumihiko 末 木文美士, Miyake Tetsujō 三宅徹誠, Kinugawa Kenji 衣川賢次, Makino Kazuo 牧野和夫, Saitō Takanobu 斉藤隆信 et al., 789810. Nanatsudera Koitsu Kyōten Kenkyū Sōsho 七寺古逸經典 叢書 [The Long Hidden Scriptures of Nanatsudera, Research Series]. Tokyo: Daitō shuppansha 大東出版社, 2000.

Apple, James B. 'The Phrase Dharmaparyāyo Hastagato in 
Mahāyāna Buddhist Literature: Rethinking the Cult of the Book in Middle Period Indian Mahāyāna Buddhism'. Journal of the American Oriental Society 134, no. 1 (2014): 25-50.

Bielefeldt, Carl W. 'Review of Tanabe and Tanabe, ed., The Lotus Sutra in Japanese Culture'. Journal of Asian Studies, 49, no. 1 (2/90), 173-75. (Revised version appeared in Wind Bell 24 [Fall 1990], 21-23.)

Blair, Heather. Real and Imagined: The Peak of Gold in Heian Japan. Cambridge: Harvard University Asia Center, 2015. - 'Rites and Rule: Kiyomori at Itsukushima and Fukuhara'. Harvard Journal of Asiatic Studies 73, no. 1 (2013): 1-42. Bock, Felicia Gressitt, trans. Engishiki: Procedures of the Engi Era. Books I-X. Monumenta Nipponica Monograph Series. Tokyo: Sophia University Press, 1970-1972.

Cai Yunchen 蔡運辰, ed. Ershiwu zhong zangjing mulu duizhao $k a o s h i$ 二十五種藏經目錄對照考釋 [Comparative Index to Twenty-Five Editions of the Printed Buddhist Canon in Chinese]. Taipei: Xinwenfeng chuban gongsi 新文豐出版公司, 1983.

Conze, Edward. The Prajñāpāramitā Literature. Indo-

Iranian Monographs. Vol. VI. The Hague: Mouton \& Co. 'S-Gravenhage, 1960.

Dai Nibon Bukkyō zensho 大日本佛教全書 [Complete Buddhist Works of Japan]. 150 vols. Tokyo: Bussho kankōkai, 1912-1922. All references are to the rpt. ed., 100 vols. Suzuki Gakujutsu Zaidan 鈴木学術財団 (Tokyo: Kōdansha, 1970-1973). de Visser, M. W. Ancient Buddhism in Japan: Sutras and Commentaries in Use in the Seventh and Eighth Centuries A.D. And Their History in Later Times. 2 vols. Leiden: E.J. Brill, 1935. Deleanu, Florin. 'The Transmission of Xuanzang's Translation of the Yogācārabbümi in East Asia: With a Philological Analysis of Scroll Xxxiii'. In Kongōji issaikyō no sōgōteki kenkyū to Kongōji shōgyō no kisoteki kenkyū: kenkyū seika bökokusho 金剛寺一 切経の総合的研究と金剛寺聖教の基礎的研究: 研究成果報 告書 [General Research on the Kongōji Manuscript Canon and a Basic Survey of the Kongōji Sacred Texts], edited by Ochiai Toshinori 落合俊典, 1-44, 632-589. Tokyo: Kokusai Bukkyōgaku daigakuin daigaku 国際仏教学大学院大学, 2007. 
Demiéville, Paul, Hubert Durt, Anna K. Seidel, and Académie des inscriptions \& belles-lettres (France). Répertoire du Canon Bouddhique Sino-Japonais, Édition de Taishō (Taishō shinshū daizōkyō): [Fascicule Annexe du Hōbogirin] [Catalogue to the Taishō era East Asian Buddhist Canon]. Revised and augmented edition. Paris: Librairie d'Amerique et d'Orient, 1978.

Drewes, David. 'Revisiting the Phrase "Sa Prthvippradeśas Caityabhūto Bhavet" and the Mahāyāna Cult of the Book'. Indo-Iranian Journal 50 (2007): 101-43.

Funayama Tōru 船山徹. Butten wa dō Kanyaku sareta no ka: sūtora ga kyōten ni naru toki 仏典はどう漢訳さらたのかースートラが 経典になるとき. [Making Sūtras into 'Classics': How Buddhist Scriptures Were Translated into Chinese]. Tokyo: Iwanami shoten 岩波書店, 2014.

Gakujutsu Furontia jikkō iinkai 学術フロンティア実行委員会, ed. Nihon genson hasshu issaikyō taishō mokuroku tsuke Tonkō Bukkyo bunken 日本現存八種一切経対照目録 [付] 敦煌仏教 文献 [Catalogue to Eight (Manuscript) Buddhist Canons in Japan with Cross Reference to the Taishō Canon and Extant Manuscripts from Dunhuang]. Tokyo: Kokusai Bukkyōgaku daigakuin daigaku 国際仏教学大学院大学, 2006.

Giebel, Rolf W., trans. 'The Chin-Kang-Ting Ching Yü-Ch'ieh Shih-Pa-Hui Chih-Kuei: An Annotated Translation'. Journal of Naritasan Institute for Buddhist Studies 18 (1995): 107201.

_. 'Taishō Volumes 18-21'. In Esoteric Buddhism and the Tantras in East Asia, edited by Charles D. Orzech, Henrik H. Sørensen and Richard K. Payne, Handbook of Oriental Studies, 25-36. Leiden: Brill, 2011.

- Two Esoteric Sutras: The Adamantine Pinnacle Sutra and the Susiddhikara Sutra (Translated from the Chinese, Taishö Volume 18, Numbers 865, 893). BDK English Tripitaka. Berkeley:

Numata Center for Buddhist Translation and Research, 2001.

—. The Vairocanābhisambodhi Sütra: Translated from the Chinese (Taishō Volume 18, Number 848). BDK English Tripitaka Series. Berkeley: Numata Center for Buddhist Translation and Research, 2005. 
Giles, Lionel. 'Dated Chinese Manuscripts in the Stein Collection, I: Fifth and Sixth Centuries A.D.'. Bulletin of the School of Oriental and African Studies 7, no. 4 (1935): 809-35.

—. 'Dated Chinese Manuscripts in the Stein Collection, Ii: Seventh Century A.D.'. Bulletin of the School of Oriental and African Studies 8, no. 1 (1935): 1-26.

- 'Dated Chinese Manuscripts in the Stein Collection, Iii: Eighth Century A.D.'. Bulletin of the School of Oriental and African Studies 9, no. 1 (1937): 1-25.

- 'Dated Manuscripts in the Stein Collection Iv. Ninth Century'. Bulletin of the School of Oriental and African Studies 9, no. 4 (1939): 1023-46.

—. 'Dated Chinese Manuscripts in the Stein Collection Vi.

Tenth Century (A.D. 947-995)'. Bulletin of the School of

Oriental and African Studies 11, no. 1 (1943): 148-73.

- Descriptive Catalogue of the Chinese Manuscripts from

Tunbuang in the British Museum. London: Trustees of the British Museum, 1957.

Grapard, Allan. 'Institution, Ritual, and Ideology: The Twenty-Two Shrine-Temple Multiplexes of Heian Japan'. History of Religions 27, no. 3 (1988): 246-69.

Gummer, Natalie D. 'Listening to the Dharmabhānaka: The Buddhist Preacher in and of the Sūtra of Utmost Golden Radiance'. Journal of the American Academy of Religion 80, no. 1 (2012): 137-60.

Hansen, Valerie. 'The Tribute Trade with Khotan in Light of Materials Found at the Dunhuang Library Cave'. Bulletin of the Asia Institute, New Series, Iranian and Zoroastrian Studies in Honor of Prods Oktor Skjaervo 19 (2005): 37-46.

Hérail, Francine. La Cour Et L'administration Du Japon a L'epoque

De Heian [The Court and Administration of Japan in the Heian Period]. École Pratique des Hautes Études, Sciences historiques et philologiques, II; Hautes Études Orientales 40; ExtrêmeOrient 5 [École Pratique des Hautes Études, Historical and Philological Sciences, II; Advanced Oriental Studies; Far East 5]. Genève: Droz, 2006.

Herrmann-Pfandt, Adelheid. Die Lhan Kar Ma Ein Früher Katalog 
Der Ins Tibetische Übersetzten Buddbistischen Texts, Kritische Neuausgabe Mit Einleitung Und Materialien [The Lan Kar ma catalogue: An early catalogue of Buddhist texts translated into Tibetan Critical new edition with introduction and materials]. Beiträge Zue Kultur - Und Geistesgeschichte Asiens [Studies in Cultural and Intellectual History of Asia]. Vol. 59. Vienna: Verlag der Österreichischen Akademie der Wissenschaften, 2008.

Hikata, Ryūshō. Suvikrāntavikrāmi-Pariprcchā-PrajñāpāramitāSütra. Fukuoka: Committee of Commemoration Program for Dr. Hikata's Retirement from Professorship, Kyūshū University, 1958. References made to rpt. ed., Kyoto: Rinsen Books, 1983.

Hirayama Asaji 平山朝治. 'Nagaya no ōkimi no Shōtoku taishi' 長屋王の聖徳太子 [Prince Shōtoku according to Prince Nagaya]. Tsukuba University Economic Review 筑波大学経済学論集 [Tsukuba daigaku keizaigaku ronshū] 60 (2008): 1-76.

$\mathrm{Hu}$, Yao. 'The Elevation of the Status of the Lotus Sütra in the Panjiao Systems of China'. Journal of Chinese Religions 42, no. 1 (2014): 67-94.

Huang Zheng 黃徵, and Wu Wei 吴偉. Dunbuang yuanwen ji 敦煌 願文集 [Collected Prayers from Dunhuang]. Changsha: Yuelu shushe 岳麓書社, 1995.

Ikeda On 池田温. Chūgoku kodai shahon shikigo shüroku 中国古 代写本識語集録 [Collected Colophons of Ancient Chinese Manuscripts]. Tokyo: Tōkyō daigaku Tōyō bunka kenkyūjo 東京大學東洋文化研究所, 1990 .

Iwamoto Taketoshi 岩本健寿. 'Nagaya no ōkimi hotsugankyō (Shigaken Jōmyōji-zō Wadōkyō) denraikyō’ 長屋王発願経(滋賀県常 明寺蔵和銅経) 伝来考 [Preliminary Study of Prince Nagaya's Vowed Scriptures from the Wadō Period]. In Bukkyō bunmei no tenkai to byōgen: moji, gengo, zōkei to shisō 仏教文明の転回と表 現: 文字・言語・造形・思想 [Expressions and Turns of Buddhist Civilization: Writing, Language, Modeling, and Thought], edited by Shinkawa Tokio 新川登亀男, 209-36. Tokyo: Bensei shuppan 勉誠出版, 2015.

Ji Xianlin 季羡林, ed. Dunbuangxue dacidian 敦煌學大辭典 [Dictionary of Dunhuang Studies]. Shanghai: Shanghai cishu 
chubanshe 上海辭書出版社, 1998.

Jōdai bunken o yomu kai 上代文献を読む会, ed. Jödai shakyō shikigo $c h \bar{u} s h a k u$ 上代写経識語注釈 [Annotated Study of Colophons to Early Manuscript Sūtras (in Nara Japan)]. Tokyo: Bensei shuppan 勉誠出版, 2016.

Karashima Seishi. A Critical Edition of Lokaksema's Translation of the Astasāhasrikā Prajñāpāramitā 道行般若經校注. Tokyo: International Research Institute for Advanced Buddhology, Soka University, 2011.

Keyworth, George A. 'Apocryphal Chinese Books in the Buddhist

Canon at Matsuo Shintō Shrine'. Studies in Chinese Religions 2, no. 3 (2016): 1-34.

—. 'Copying for the Kami: On the Manuscript Set of the Buddhist Canon Held by Matsuno'o Shrine'. Japanese Journal of Religious Studies 44, no. 2 (2017): 161-90.

Kieschnick, John. The Impact of Buddhism on Chinese Material Culture. Buddhisms. Princeton, Oxford: Princeton University Press, 2003.

Kochinski, Lisa. 'Negotiations between the Kami and Buddha Realms: The Establishment of Shrine-Temples in the Eighth Century'. Journal of Asian Humanities at Kyushu University 1 (2016): 39-45.

Kokan Shiren 虎関師錬 (1278-1346), and Fujita Takuji 藤田玩 司. Kundoku Genkō shakusho 訓読元亨釈書 [Japanese reading of Kokan Shiren's Buddhist History of the Genkō Era (13211324)]. Kyoto: Zen bunka kenkyūjo 禅文化研究所, 2011.

Komine Michihiko 小峰未彌彦, Katsuzaki Yūgen 勝崎祐彦, and Watanabe Shōgo 渡辺章悟. Hannyakyō taizen 般若経大全 [Encyclopedia of Prajñāpāramitā Scriptures]. Tokyo: Shunjūsha 春秋社, 2015.

Kornicki, Peter. The Book in Japan: A Cultural History from the Beginnings to the Nineteenth Century. Leiden: E.J. Brill, 1998. Honolulu: University of Hawai'i, 2001.

Kyoto National Museum, ed. The Eastward Expansion of Buddhism: Art of the Buddhist Canon; Feature Exhibition in Commemoration of the 100th Daizō-E Exhibition (Buppō tōzen: Bukkyō no tenseki to bijutsu--tokubetsu tenkan dai byakkai daizō-e 
kinen 仏法東漸: 仏教の典籍と美術一特別展観第100回大藏会記 念). Edited by Consortium of Buddhist Universities and Colleges in Kyoto, Kyoto National Museum. Kyoto: Kyoto National Museum, 2015.

Lancaster, Lewis. 'The Movement of Buddhist Texts from India to China and the Construction of the Chinese Buddhist Canon'. In Buddhism across Boundaries, Sino-Platonic Papers No. 222, edited by John R. McRae and Jan Nattier, 226-38. Philadelphia: Department of East Asian Languages and Civilizations, University of Pennsylvania, 2012.

Lancaster, Lewis R., and Sung-bae Park, eds. The Korean Buddhist Canon: A Descriptive Catalogue. Berkeley: University of California Press, 1979.

Lévi, Sylvain, Takakusu Junjirō 高楠順次郎, Paul Demiéville, Watanabe Kaikyoku 渡辺海旭, Ōtani and Wada Foundation, Tokyo Imperial Academy, and Taishō shinshu Daizōkyō 大正 新脩大蔵経. Hōbōgirin 法寶義林: Dictionnaire Encyclopédique De Bouddhisme D'après Les Sources Chinoises Et Japonaises [The Grove of Meanings of Dharma Treasure: Encyclopedic Dictionary of Buddhism from the Chinese and Japanese Sources]. 1 (1929), 2 (1930), 3 (1937), 4 (1967), 5 (1979), 6 (1983), 7 (1994), 8 (2003), 9 (nd) vols. Tokyo: Maison franco-japonaise, 1929-.

Li, Fuhua. 'An Analysis of the Content and Characteristics of the Chinese Buddhist Canon'. Studies in Chinese Religions 2, no. 2 (2016): 107-28.

Li, Rongxi. A Biography of the Tripitaka Master of the Great Cien Monastery of the Great Tang Dynasty, Translated from the Chinese of Sramana Huili and Yancong (Taishō, Volume 50, Number 2053). BDK English Tripitaka 77. Berkeley: Numata Center for Buddhist Translation and Research, 1995.

Liu, Ming-wood. 'The Advent of the Practice of P'an-Chiao in Chinese Buddhism'. Journal of Oriental Studies 26, no. 1 (1988): $1-27$.

. 'The Chinese Madhyamaka Practice of P'an-Chiao: The Case of Chi-Tsang'. Bulletin of the School of Oriental and African Studies 56, no. 1 (1993): 96-118.

—. 'The P'an-Chiao System of the Hua-Yen School in Chinese 
Buddhism'. T'oung Pao 67, no. 1-2 (1981): 10-47.

Lopez, Donald S., Jr. The Lotus Sütra: A Biography. Lives of Great

Religious Books. Princeton: Princeton University Press, 2016.

Lowe, Bryan. 'Contingent and Contested: Preliminary Remarks on

Buddhist Catalogs and Canons in Early Japan'. Japanese Journal

of Religious Studies 41, no. 2 (2014): 221-53.

Lusthaus, Dan. Buddhist Phenomenology: A Philosophical Investigation of Yogàcāra Buddhism and the Ch'eng Wei-Shih Lun. Curzon

Critical Studies in Buddhism 13. London: Curzon, 2002.

Matsuno’o taisha shiryōshū henshū iinkai 松尾大社史料集編集委員 会. Matsuno'o taisha shiryōshū: monjo hen 松尾大社史料集: 文 書編 [Collected Historical Documents from Matsuo Shrine: Documents]. 4 vols. Vol. 1. Tokyo: Yoshikawa Kōbunkan 吉川弘 文館, 1977.

McCallum, Donald F. The Four Great Temples: Buddhist Archaeology, Architecture, and Icons of Seventh-Century Japan.

Honolulu: University of Hawai'i Press, 2009.

McMullin, Neil. Buddhism and the State in 16th Century Japan. Princeton: Princeton University Press, 1985.

- 'The Lotus Sutra and Politics in the Mid-Heian Period'. In The Lotus Sutra in Japanese Culture, edited by George J. Tanabe and Willa Jane Tanabe, 119-41. Honolulu: University of Hawai'i Press, 1989.

Mingban Jiaxing dazang jing: Jingshan zangban 明版嘉興大藏經:

徑山藏版 [Ming dynasty printed Jiaxing Chinese Buddhist Canon; Mount Jing edition]. 40 vols. 1579-1707. Rpt., Taipei: Xinwenfeng chuban gongsi 新文豐出版公司, 1986-1987. Digital version, Chinese Buddhist Electronic Text Association, CBETA Chinese Electronic Tripitaka Collection, Taipei, CBETA, 1998-2018.

Miyabayashi Akihiko 宮林昭彦, and Ochiai Toshinori 落合俊典. 'Zhenyuan xinding shijiao mulu juandi 貞元新定釋教目錄 29 30'. In Chügoku Nihon kyōten shōsho mokuroku 中國・日本經典 章疏目録 [Catalogues of Scriptures and Their Commentaries in China and Japan], edited by Makita Tairyō 牧田諦亮, A. Forte, Miyabayashi Akihiko 宮林昭彦, Ochiai Toshinori 落合俊典, Saitō Takanobu 斉藤隆信, Miyazaki Kenji 宮崎健司, Kajiura Susumu 梶浦晋, Ouchi Fumio 大内文雄, and G. Paul, 59-128. 
Nanatsudera koitsu kyōten kenkyū sōsho 七寺古逸經典叢書 [The Long Hidden Scriptures of Nanatsudera, Research Series]. Tokyo: Daitō shuppansha 大東出版社, 1998.

Moerman, D. Max. 'The Archaeology of Anxiety: An Underground History of Heian Religion'. In Heian Japan, Centers and Peripheries, edited by Mikael S. Adolphson, Edward Kamens and Stacie Matsumoto, 245-71. Honolulu: University of Hawai'i Press, 2007.

L Localizing Paradise: Kumano Pilgrimage and the Religious Landscape of Premodern Japan. Cambridge: Harvard University Press, 2005.

Mujaku Dōchū 無著道忠. Zenrin shōkisen 禅林象器箋 [Notes on Images and Implements from the Groves of Zen]. Kyoto: Seishin shobō 誠信書房, 1963.

Nakano, Chieko. “"Kechien” as Religious Praxis in Medieval Japan: Picture Scrolls as the Means and Sites of Salvation'. Ph.D. dissertation, University of Arizona, 2009.

Nakao Takashi 中尾堯, and Honmon hokkeshū daihonzan Myōrenji 本門法華宗大本山妙蓮寺, eds. Kyōto Myōrenji-zo' 'Matsuosha issaikyō chōsa hōkokusho 京都妙蓮寺蔵「松尾社一切経」調査報告 書 [Catalogue of the Matsuno'o Shrine Canon held at Myōrenji]. Tokyo: Ōtsuka kōgeisha 大塚巧藝社, 1997.

Nanatsudera issaikyō hozonkai 七寺一切経保存会. Owari shiryō Nanatsudera issaikyō mokuroku 尾張史料七寺一切経目録. [Catalogue of the Natsudera scriptures]. Nagoya: Nanatsudera issaikyō hozonkai 七寺一切経保存会, 1968.

Nara National Museum 奈良国立博物館, ed. Special Exhibit of Ancient Sutras from the Heian Period: Encountering the

Legendary Kunōji Sutras. Tenri: Tenri Jihōsha 天理時報社, 2015.

Obermiller, Evgeni i Evgenévich. History of Buddhism (ChosHbyung). Materialien Zur Kunde Des Buddhismus 18-19 Heft [Materials for Buddhist Studies, Issues 18-19]. Heidelberg: In kommission bei O. Harrassowitz, 1931.

Ochiai Toshinori 落合俊典, ed. Kongōji issaikyō no sōgōteki kenkyū to Kongōji shōgyō no kisoteki kenkyū 金剛寺一切経の総合的研究 と金剛寺聖教の基礎的研究 [General Research on the Kongōji Manuscript Canon and a Basic Survey of the Kongōji Sacred 
Texts]: Heisei 16 18 nendo kagaku kenkyübi hojokin kiban kenkyū $(A)$ kenkyū seika bōkokusho 平成 16 18 年度科学研究費 補助金基盤研究 (A) 研究成果報告書 [2004-2006 Grant-in-Aid Scientific Research (category A) Research Report vol. 1]. 2 vols. Tokyo: Kokusai Bukkyōgaku daigakuin daigaku 国際仏教学大学 院大学, 2007.

Ochiai, Toshinori, Antonino Forte, Tairyō Makita, and Silvio Vita. The Manuscripts of Nanatsu-Dera: A Recently Discovered Treasure-House in Downtown Nagoya. Kyoto: Istituto italiano di cultura Scuola di studi sull'Asia orientale, 1991.

Ochiai Toshinori 落合俊典, Frédéric Girard, and Li-Ying Kuo.

'Découverte de manuscrits bouddhiques chinois au Japon [Conférence prononcée par Monsieur Ochiai Toshinori]' [Discovery of Chinese Buddhist manuscripts in Japan: Lecture by Mr. Ochiai Toshinori]. Bulletin de l'École française d'ExtrêmeOrient [Bulletin of the French School of Asian Studies] 83 (1996): 368-75.

Ooms, Herman. Imperial Politics and Symbolics in Ancient Japan:

The Tenmu Dynasty, 650-800. Honolulu: University of Hawai' $\mathrm{i}$ Press, 2009.

Orzech, Charles D. Politics and Transcendent Wisdom: The Scripture for Humane Kings in the Creation of Chinese Buddhism.

University Park: Pennsylvania State University Press, 1998.

Ōtsuka Norihiro 大塚紀弘. 'Issaikyō shosha to butten mokuroku: Aichiken Shinshiroshi Tokuunji zō Heian koshakyō no bunseki kara'一切経書写と仏典目録一愛知県新城市徳運寺蔵平安古写 経の分析からー [Catalogue of Buddhist Scriptures Copied in a Heian-Era Buddhist Canon from Tokuunji in Aichi Prefecture, Shinshiro City]. In Tokuunji no ko shakyō: Aichiken Shinshiroshi Tokuunji ko shakyō chōsa hōkoku-sho 徳運寺の古寫經: 愛知縣新 城市徳運寺古寫經調査報告書 [Old manuscripts of the Tokuunji temple: Investigation report of the old manuscripts at the Tokuunji temple in the city of Shinshiro, Aichiken Prefecture], edited by Kokusai Bukkyōgaku daigakuin daigaku gakujutsu furonntia Jikkō iinkai 国際仏教学大学院大学学術フロンティア 実行委員会, 39-54. Tokyo: Kokusai Bukkyōgaku daigakuin daigaku 国際仏教学大学院大学, 2009. 
Pelliot collection of Chinese manuscripts at Dunhuang (Bibliothèque Nationale, Paris). International Dunhuang Project online database. http://idp.bl.uk.

Risshō University Academy 立正大学学園, and Nakao Takashi 中尾 堯. Maboroshi no issaikyō' bakken-Myörenji kura Matsuno'osha issaikyōo megutte 幺𠃌一切経' 発見一妙蓮寺蔵「松尾社一切 経」をめぐって [Discovery of a Hidden [Buddhist] Canon: Tour of the Matsuno'o shrine [Buddhist] Canon from the Storehouse of Myōrenji (Temple)]. Kyoto: Kyoto bunka hakubutsukan 京都 文化博物館, 1995 .

Rong Xinjiang 榮新江. Eighteen Lectures on Dunbuang. Translated by Imre Galambos. Brill's Humanities in China Library. Vol. 5. Leiden: Brill, 2013.

_. 'The Nature of the Dunhuang Library Cave and the Reasons for Its Sealing'. Cabiers d'Extrême Asie [East-Asian Journal] 11 (1999-2000): 247-75.

Sagai Tatsuru 嵯峨井建. Shinbutsu shūgō no rekishi to girei kūkan 神仏習合の歴史と儀礼空間 [History of Shintō-Buddhist Syncretism and Ritual Space]. Kyoto: Shibunkaku 思文閣, 2013. Sango, Asuka. 'Buddhist Debate and the Production and Transmission of Shōgyō in Medieval Japan'. Japanese Journal of Religious Studies 39, no. 2 (2012): 241-73.

- The Halo of Golden Light: Imperial Authority and Buddhist Ritual in Heian Japan. Honolulu: University of Hawai'i Press, 2015.

Schmid, Neil. 'Introduction to Tun-Huang and Its Manuscripts'. In The Columbia History of Chinese Literature, edited by Victor $\mathrm{H}$. Mair, 964-88. New York: Columbia University Press, 2001. Schopen, Gregory. 'The Generalization of an Old Yogic Attainment in Medieval Mahāyāna Sūtra Literature: Some Notes on Jatismara'. Journal of the International Association for Buddhist Studies 6, no. 1 (1983): 109-47.

—. 'The Mahāyāna and the Middle Period in Indian Buddhism: Through a Chinese Looking-Glass'. The Eastern Buddhist 32, no. 2 (2000): 1-25.

_. 'On the Absence of Urtexts and Otiose Ācāryas: Buildings, Books, and Lay Buddhist Ritual at Gilgit'. In Écrire Et 
Transmettre En Inde Classique [Writing And Transmission In Classical India], edited by Gérard Colas and Gerdi Gerschheimer, 189-212. Paris: École Française d'Extrême-Orient, 2009.

—. 'The Phrase Sa Prthivīpradeśas' Caityabbüto Bhavet in the Vajracchedikā: Notes on the Cult of the Book in the Mahāyāna'. Indo-Iranian Journal 17 (1975): 147-81.

_. 'Redeeming Bugs, Birds, and Really Bad Sinners in Some Medieval Mahāyāna Sūtras and Dhāraṇīs'. In Sins and Sinners: Perspectives from Asian Religions, edited by Phyllis Granoff and Koichi Shinohara, 276-94. Leiden, Boston: Brill, 2012. Sheng, Ruth. 'The Development of Chinese Calligraphy in Relation to Buddhism and Politics During the Early Tang Era'. Ph.D. dissertation. University of Florida, 2011.

Shively, Donald H., and William H. McCullough, ed. The Cambridge History of Japan, Vol. 2, Heian Japan. New York: Cambridge University Press, 1999.

Stein collection of Chinese manuscripts from Dunhuang (British Library, London). International Dunhuang Project online database. http://idp.bl.uk.

Storch, Tanya. The History of Chinese Buddhist Bibliography: Censorship and Transformation of the Tripitaka. Amherst: Cambria Press, 2014.

Takakusu Junjirō 高楠順次郎, and Watanabe Kaigyoku 渡邊海旭, eds. Taishō shinshū daizōkyō 大正新脩大藏經 [Revised version of the East Asian Buddhist Canon, compiled during the Taishō era]. 100 vols. Tokyo: Taishō issaikyō kankōkai, 1924-1932. Rpt., Chinese Buddhist Electronic Texts Association 中華電 子佛典栛會, CBETA Electronic Tripitaka Collection 電子佛典 集成, Taipei: 1998-2020. http://cbetaonline.dila.edu.tw. SAT Daizōkyō Database ver. 2018. http://21dzk.l.u-tokyo.ac.jp/ SAT2018/master30.php.

Takeda Goichi 武田悟一. 'Nagamatsu Nissen ni okeru kyōka katsudō no kenkyū: Shimada-shi to no kōryū o chūshin to shite' 長松日 扇における教化活動の研究 : 嶋田氏との交流を中心として [Study of the Influence of Nagamatsu Nissen's Educational Activities upon Mr. Shimada]. Shükyō kenkyū 宗教研究 [Studies of Religion] 82, no. 4 (2009): 1264-65. 
Tanabe, George Joji, and Willa J. Tanabe, eds. The Lotus Sutra in Japanese Culture. Honolulu: University of Hawai'i Press, 1989.

Teiser, Stephen F. 'Ornamenting the Departed: Notes on the Language of Chinese Buddhist Ritual Texts'. Asia Major, Third Series 22, no. 1 (2009): 201-37.

- The Scripture on the Ten Kings and the Making of Purgatory in Medieval Chinese Buddhism. Studies in East Asian Buddhism, No. 9. Honolulu: University of Hawai'i Press, 1994.

Tokuno, Kyoko. 'The Evaluation of Indigenous Scriptures in Chinese Buddhist Bibliographical Catalogues'. In Chinese Buddhist Apocrypha, edited by Robert E. Buswell, Jr., 31-74. Honolulu: University of Hawai'i Press, 1990.

van Schaik, Sam. 'The Uses of Implements Are Different: Reflections on the Functions of Tibetan Manuscripts'. In Tibetan Manuscript and Xylograph Traditions: The Written Word and Its Media within the Tibetan Cultural Sphere, edited by Orna Almogi, 221-42. Hamburg, New Delhi: Department of Indian and Tibetan Studies, Asien-Afrika-Institut, Universität Hamburg and Replika Press, 2016.

Waley, Arthur. The Real Tripitaka, and Other Pieces. New York: Macmillan, 1952.

Wong, Dorothy. Buddhist Pilgrim-Monks as Agents of Cultural and Artistic Transmission: The International Buddhist Art Style in East Asia, ca. 645-770. Singapore: National University of Singapore Press, 2018.

_ 'The Making of a Saint: Images of Xuanzang in East Asia'. Early Medieval China 8 (2002): 43-81.

Wriggins, Sally Hovey. The Silk Road Journey with Xuanzang. Boulder: Westview Press, 2003. Rev. updated ed., Xuanzang: A Buddhist Pilgrim on the Silk Road (Boulder: Westview Press, 1996).

Wu, Jiang. "From the "Cult of the Book" to the "Cult of the Canon": A Neglected Tradition in Chinese Buddhism'. In Spreading the Buddha's Word in East Asia: The Formation and Transformation of the Chinese Buddhist Canon, edited by Jiang Wu and Lucille Chia, 46-78. New York: Columbia University Press, 2016. 
Wu, Jiang, Greg Wilkinson, Fang Guangchang, J. Frederick, Tomoo Kida, Richard D. II McBride, A. Charles Muller et al., ed. Reinventing the Tripitaka: Transformation of the Buddhist Canon in Modern East Asia. Lanham: Lexington Books, 2017.

Zhang, Dewei. 'An Unforgettable Enterprise by Forgotten Figures: The Making of the Zhaocheng Canon 趙城藏 in North China under the Jurchen Regime'. Zinbun: Memoirs of the Research Institute for Humanistic Studies 44 (2014): 13-50. 